Prepared in cooperation with Department of the Navy, Naval Facilities Engineering Command, Northwest

\title{
Groundwater Geochemical and Selected Volatile Organic Compound Data, Operable Unit 1, Naval Undersea Warfare Center, Division Keyport, Washington, June 2011
}

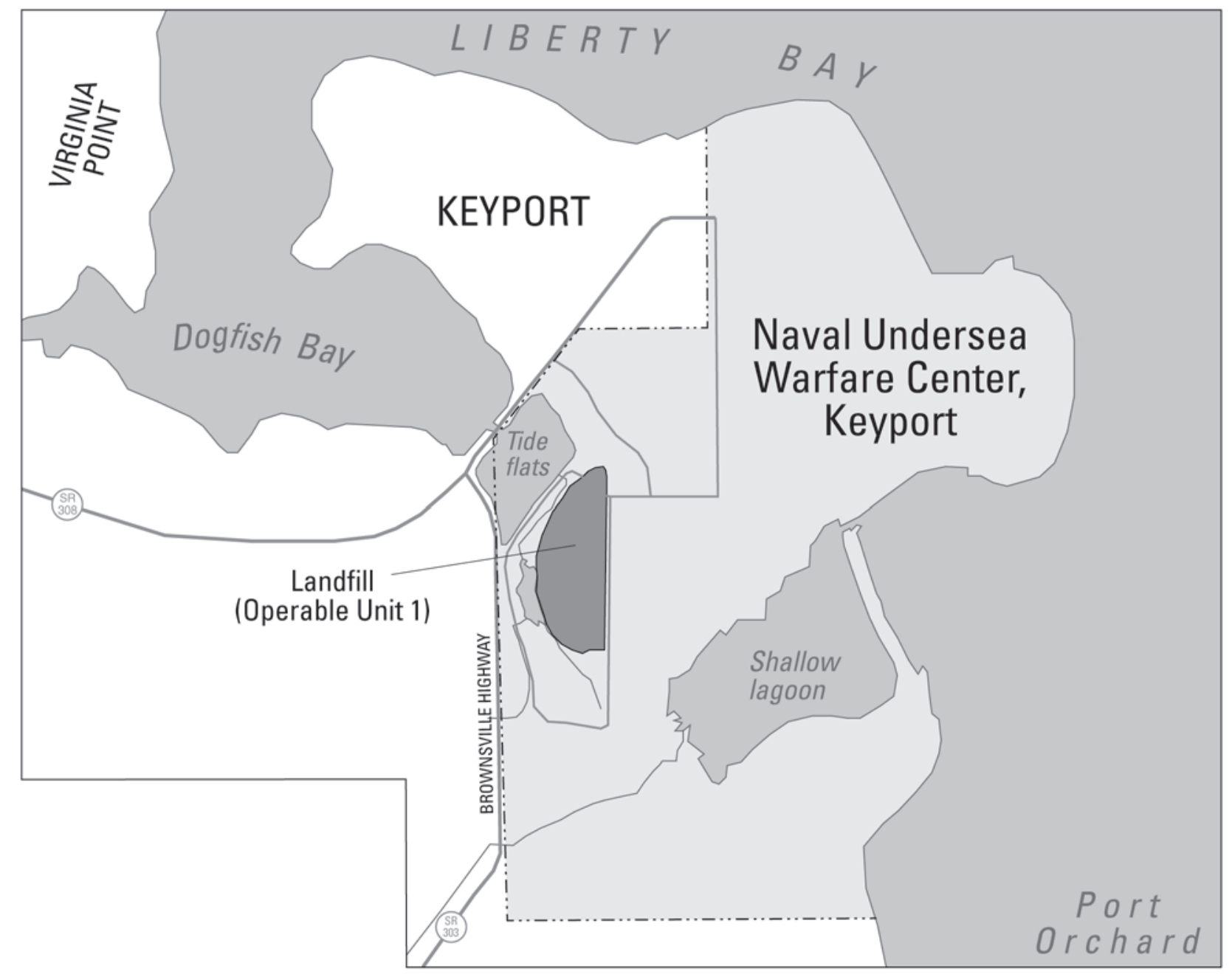

Data Series 731 



\section{Groundwater Geochemical and Selected Volatile Organic Compound Data, Operable Unit 1, Naval Undersea Warfare Center, Division Keyport, Washington, June 2011}

By R.L. Huffman and L.M. Frans

Prepared in cooperation with the Department of the Navy, Naval Facilities

Engineering Command, Northwest

Data Series 731 


\section{U.S. Department of the Interior \\ KEN SALAZAR, Secretary \\ U.S. Geological Survey \\ Marcia K. McNutt, Director}

\section{U.S. Geological Survey, Reston, Virginia: 2012}

For more information on the USGS - the Federal source for science about the Earth, its natural and living resources, natural hazards, and the environment, visit http://www.usgs.gov or call 1-888-ASK-USGS

For an overview of USGS information products, including maps, imagery, and publications, visit http://www.usgs.gov/ pubprod

To order this and other USGS information products, visit http://store.usgs.gov

Any use of trade, product, or firm names is for descriptive purposes only and does not imply endorsement by the U.S. Government.

Although this report is in the public domain, permission must be secured from the individual copyright owners to reproduce any copyrighted materials contained within this report.

Suggested citation:

Huffman, R.L., and Frans, L.M., 2012, Groundwater geochemical and selected volatile organic compound data, Operable Unit 1, Naval Undersea Warfare Center, Division Keyport, Washington, June 2011: U.S. Geological Survey Data Series 731, $40 \mathrm{p}$. 


\section{Contents}

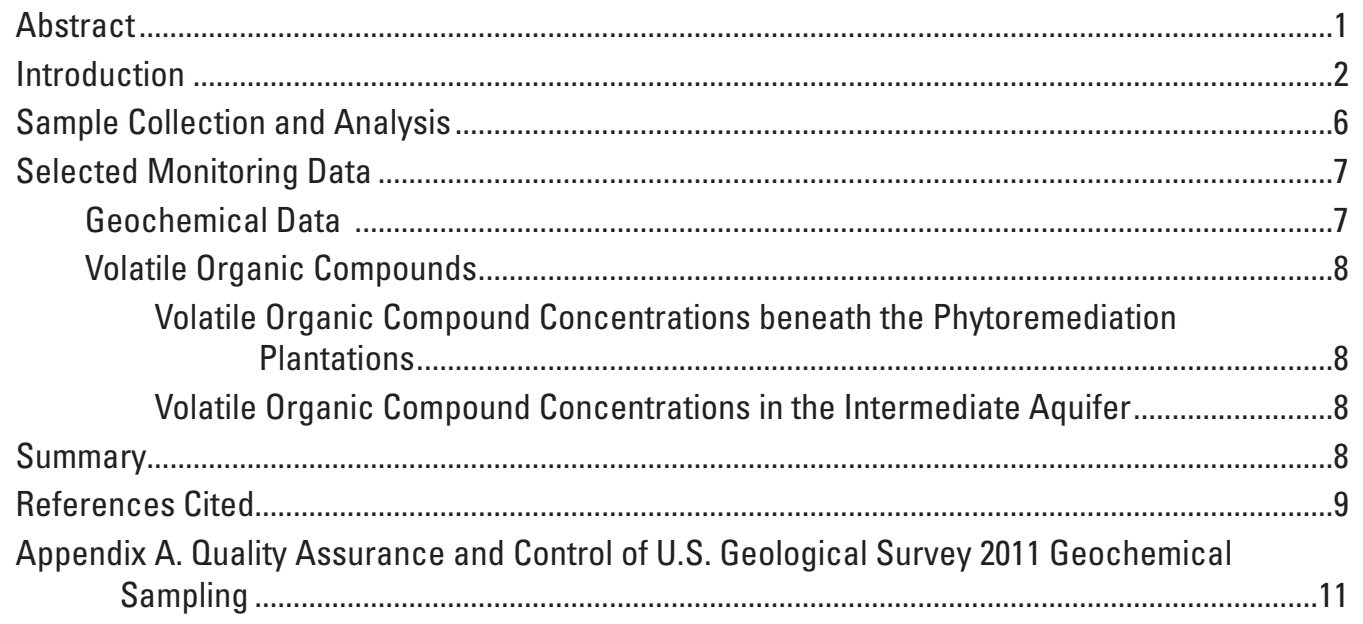

\section{Figures}

Figure 1. Map showing location of the study area near Operable Unit 1, Naval Undersea Warfare Center, Division Keyport, Washington ............................ 3

Figure 2. Map showing locations of data-collection sites used to monitor the natural attenuation of chlorinated volatile organic compounds in groundwater beneath the 9-acre former landfill at Operable Unit 1, Naval Undersea Warfare Center, Division Keyport, Washington

\section{Tables}

Table 1. Wells and piezometers sampled and groundwater levels at Operable Unit 1, Naval Undersea Warfare Center, Division Keyport, Washington, 2011

Table 2. Groundwater geochemical data collected at Operable Unit 1, Naval Undersea Warfare Center, Division Keyport, Washington, 1996-2011

Table 3. Concentrations of selected volatile organic compounds in groundwater samples from monitoring wells and piezometers collected by the U.S. Geological Survey at Operable Unit 1, Naval Undersea Warfare Center, Division Keyport, Washington, 1999-2011 


\section{Conversion Factors and Datums}

Conversion Factors

\begin{tabular}{|c|c|c|}
\hline Multiply & By & To obtain \\
\hline \multicolumn{3}{|c|}{ Length } \\
\hline inch (in.) & 2.54 & centimeter $(\mathrm{cm})$ \\
\hline inch (in.) & 25.4 & millimeter (mm) \\
\hline foot (ft) & 0.3048 & meter (m) \\
\hline \multicolumn{3}{|c|}{ Area } \\
\hline acre & 4,047 & square meter (m2) \\
\hline acre & 0.4047 & hectare (ha) \\
\hline acre & 0.4047 & square hectometer (hm2) \\
\hline acre & 0.004047 & square kilometer (km2) \\
\hline
\end{tabular}

Temperature in degrees Celsius $\left({ }^{\circ} \mathrm{C}\right)$ may be converted to degrees Fahrenheit $\left({ }^{\circ} \mathrm{F}\right)$ as follows:

${ }^{\circ} \mathrm{F}=\left(1.8 x^{\circ} \mathrm{C}\right)+32$.

Specific conductance is given in microsiemens per centimeter at 25 degrees Celsius $(\mu \mathrm{S} / \mathrm{cm}$ at $\left.25^{\circ} \mathrm{C}\right)$.

Concentrations of chemical constituents in water are given either in milligrams per liter ( $\mathrm{mg} / \mathrm{L}$ ) or micrograms per liter $(\mu \mathrm{g} / \mathrm{L})$.

Datums

Vertical coordinate information is referenced to North American Vertical Datum of 1988 (NAVD 88).

Horizontal coordinate information is referenced to North American Datum of 1927 (NAD 27).

Altitude, as used in this report, refers to distance above the vertical datum. 


\title{
Groundwater Geochemical and Selected Volatile Organic Compound Data, Operable Unit 1, Naval Undersea Warfare Center, Division Keyport, Washington, June 2011
}

\author{
By R.L. Huffman and L.M. Frans
}

\begin{abstract}
Previous investigations indicate that concentrations of chlorinated volatile organic compounds are substantial in groundwater beneath the 9-acre former landfill at Operable Unit 1, Naval Undersea Warfare Center, Division Keyport, Washington. Phytoremediation combined with ongoing natural attenuation processes was the preferred remedy selected by the U.S. Navy, as specified in the Record of Decision for the site. The U.S. Navy planted two hybrid poplar plantations on the landfill in spring 1999 to remove and to control the migration of chlorinated volatile organic compounds in shallow groundwater. The U.S. Geological Survey has continued to monitor groundwater geochemistry to ensure that conditions remain favorable for contaminant biodegradation as specified in the Record of Decision. This report presents groundwater geochemical and selected volatile organic compound data collected at Operable Unit 1 by the U.S. Geological Survey during June 20-22, 2011, in support of long-term monitoring for natural attenuation.

In 2011, groundwater samples were collected from 13 wells and 9 piezometers. Samples from all wells and piezometers were analyzed for redox sensitive constituents and dissolved gases, and samples from 5 of 13 wells and all piezometers also were analyzed for chlorinated volatile organic compounds. Concentrations of redox sensitive constituents measured in 2011 were consistent with previous years, with dissolved oxygen concentrations all at 0.4 milligram per liter or less; little to no detectable nitrate; abundant dissolved manganese, iron, and methane; and commonly detected sulfide.
\end{abstract}

\begin{abstract}
The reductive declorination byproducts-methane, ethane, and ethene-were either not detected in samples collected from the upgradient wells in the landfill and the upper aquifer beneath the northern phytoremediation plantation or were detected at concentrations less than those measured in 2010. Chlorinated volatile organic compound concentrations in 2011 at most piezometers were similar to or slightly less than chlorinated volatile organic compound concentrations measured in previous years.

For the upper aquifer beneath the southern phytoremediation plantation, chlorinated volatile organic compound concentrations in 2011 in groundwater from the piezometers were extremely high and continued to vary considerably over space and between years. At piezometer P1-9, the total chlorinated volatile organic compound concentrations increased from 9,500 micrograms per liter in 2010 to more than 44,000 micrograms per liter in 2011. Total chlorinated volatile organic compound concentrations decreased at piezometers P1-6, P1-7, and P1-10 compared to the concentrations measured in 2010. One or both of the reductive dechlorination byproducts ethane and ethene were detected at all piezometers and three of the four wells in the southern plantation.

For the intermediate aquifer, concentrations of redox sensitive constituents and chlorinated volatile organic compounds in 2011 were consistent with concentrations measured in previous years, with the exception of notable decreases in sulfate and chloride concentrations at well MW1-28. Concentrations of the reductive dechlorination byproducts ethane and ethene decreased at wells MW1-25 and MW1-28 compared to previously measured concentrations.
\end{abstract}




\section{Introduction}

Chlorinated volatile organic compounds (CVOCs) have migrated to ground water beneath a former 9-acre landfill at Operable Unit 1 (OU 1) of the Naval Undersea Warfare Center (NUWC), Division Keyport, Washington. The NUWC is on a small peninsula in Kitsap County, Washington, in an extension of Puget Sound called Liberty Bay (ig. 1). The former landfill is on the narrow strip of land connecting the peninsula to the mainland and is adjacent to tidal flats that are an extension of Liberty and Dogfish Bays. The OU 1 landfill was constructed in a former marshland and was the primary disposal area for domestic and industrial waste generated by NUWC Division Keyport from the 1930s through 1973.

Groundwater beneath OU 1 is within a series of aquifers that are composed of permeable sand, gravel, or fill materials separated by finer grained silt or clay layers. Volatile organic compound (VOC) contamination at OU 1 is only in about the top $60 \mathrm{ft}$ of the unconsolidated deposits in the four hydrogeologic units - the unsaturated zone, the upper aquifer, the middle confining unit, and the intermediate aquifer. Groundwater in the unconfined upper aquifer generally flows from the east to the west toward Dogfish Bay. Groundwater in the predominantly confined intermediate aquifer flows toward the landfill from the south and from the west, and then flows northwest beneath the landfill toward Dogfish Bay (Dinicola and others, 2002). Two perennial freshwater creeks drain the marsh adjacent to the landfill and discharge into the tide flats of Dogfish Bay.

CVOCs are in the upper and intermediate aquifers and in surface water at OU 1. The predominant contaminants in groundwater beneath OU 1 are the chloroethene compoundstrichloroethene (TCE), cis-1,2-dichloroethene (cis-DCE), and vinyl chloride (VC). Less predominant contaminants include tetrachloroethene (PCE), trans-1,2-dichloroethene (trans-DCE), 1,1-dichloroethene (1,1-DCE); and the chloroethane compounds-1,1,1-trichloroethane (TCA), 1,1-dichloroethane (1,1-DCA), and 1,2-dichloroethane (1,2-DCA). A need for remedial action was identified because some of the contaminants present a potential risk to humans, primarily through drinking contaminated groundwater or through ingesting seafood harvested from contaminated surface water (URS Consultants, Inc., 1998). The U.S. Navy planted two hybrid poplar plantations on the landfill (fig. 2) in spring 1999 to remove and control the migration of CVOCs in shallow groundwater. The landfill between the plantations is covered with pavement, although the area north of the northern plantation is permeable.

The U.S. Navy began a cooperative effort with the U.S. Geological Survey (USGS) in 1995 to evaluate the effectiveness of natural attenuation processes for removing and controlling the migration of CVOCs in groundwater at OU 1. Field and laboratory studies from 1996 through 2000 demonstrated that biodegradation of CVOCs in shallow groundwater at OU 1 was substantial (URS Consultants, Inc., 1997; Bradley and others, 1998; Dinicola and others, 2002). In 1998, a remedy was developed for contaminated groundwater at OU 1 that includes phytoremediation and on-going natural attenuation processes to remove and control the migration of CVOCs in shallow groundwater (URS Consultants, Inc., 1998). In 1999, the U.S. Navy planted two hybrid poplar plantations in two areas on the landfill where contaminant concentrations in groundwater were exceptionally high (fig. 2) (URS Greiner, Inc., 1999). The U.S. Navy regularly monitored contaminant concentrations in groundwater and surface water, along with tree health and water levels, to determine the effectiveness of phytoremediation (CH2M Hill Constructors, Inc., 2002, 2003, 2004, 2005). The USGS monitored geochemistry and contaminant concentrations in groundwater and surface water annually from 2001 through 2011 to evaluate reduction-oxidation (redox) conditions and CVOC biodegradation.

This report presents groundwater geochemical and selected CVOC data collected by the USGS at OU 1 during June 20-22, 2011, in support of the long-term monitoring for natural attenuation. The USGS collected groundwater samples from 13 wells and 9 piezometers in 2011 (table 1 and fig. 2), and concentrations of various geochemical constituents used to determine redox conditions were determined in all samples. Concentrations of VOCs also were determined by the USGS in samples collected from the nine upper aquifer piezometers and five intermediate aquifer wells in 2011. 


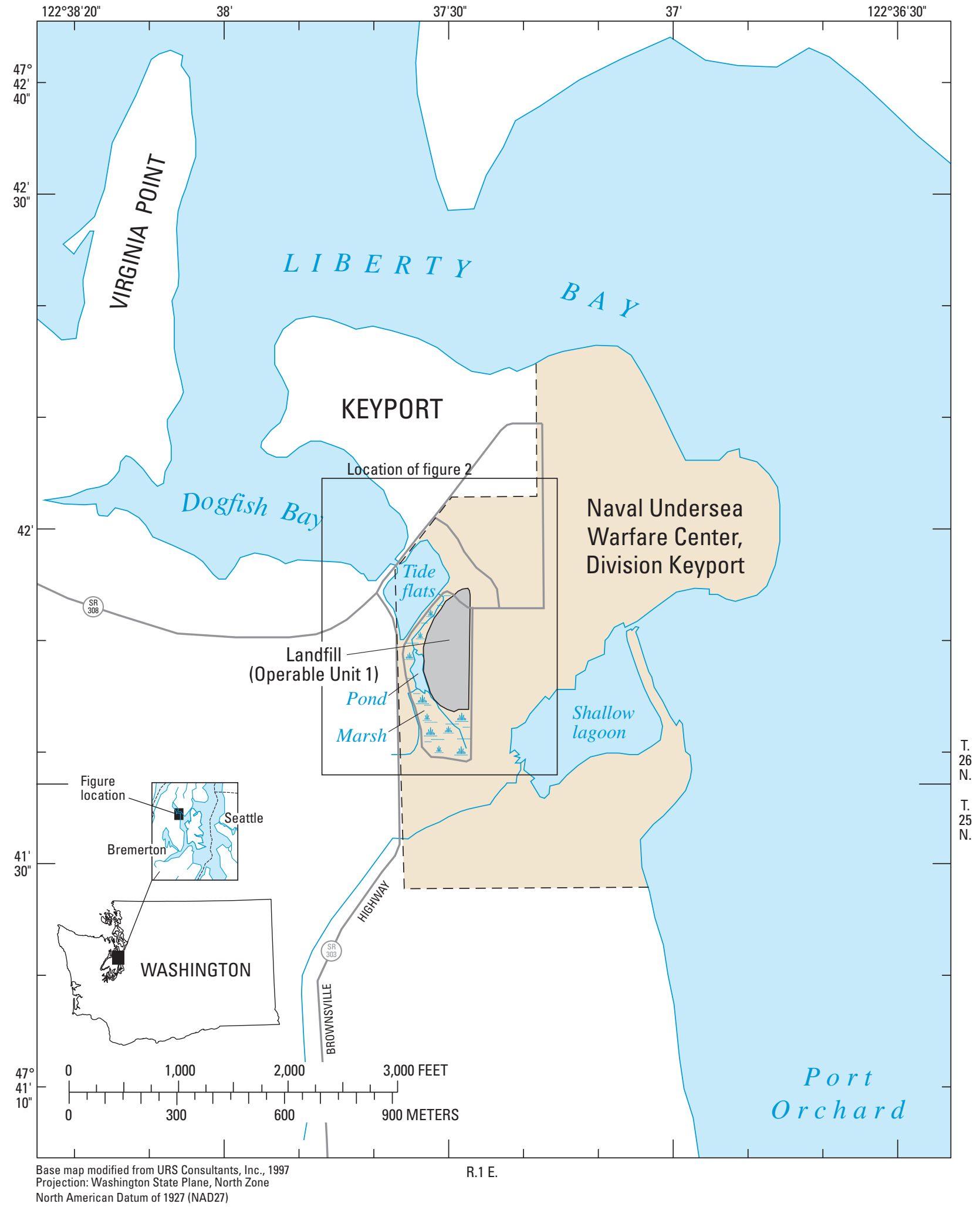

Figure 1. Location of the study area near Operable Unit 1, Naval Undersea Warfare Center, Division Keyport, Washington. 


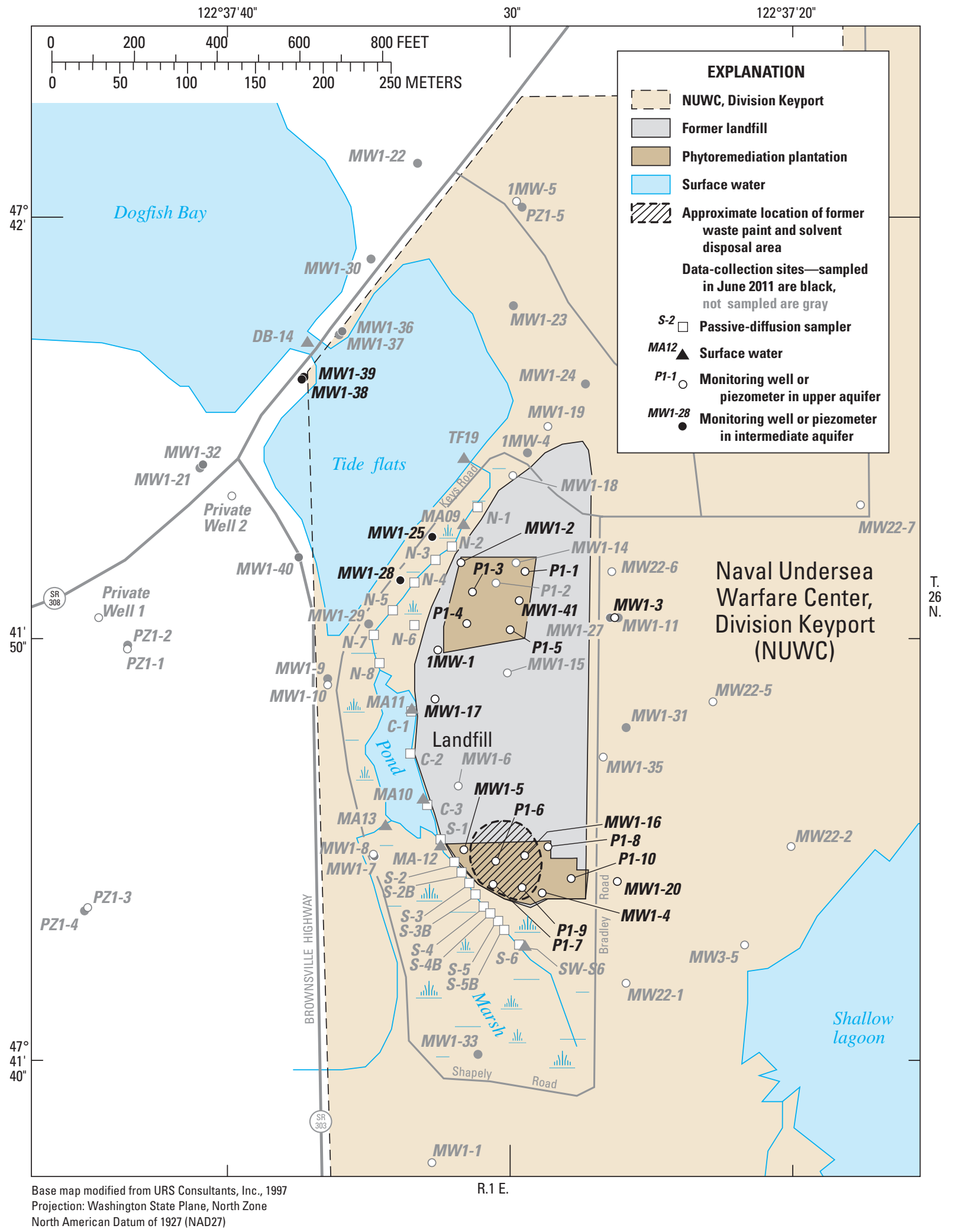

Figure 2. Locations of data-collection sites used to monitor the natural attenuation of chlorinated volatile organic compounds in groundwater beneath the 9 -acre former landfill at Operable Unit 1, Naval Undersea Warfare Center, Division Keyport, Washington. 
Table 1. Wells and piezometers sampled and groundwater levels at Operable Unit 1, Naval Undersea Warfare Center, Division Keyport, Washington, 2011.

[Well or piezometer site No.: MW, monitoring well; P, piezometer. USGS site No.: Unique number for each site based on latitude and longitude of the site. First six digits are latitude, next seven digits are longitude, and final two digits are a sequence number to uniquely identify each site. Altitudes of groundwater levels and measuring points are given in feet above or below (-) North American Vertical Datum of 1988. Water level is in feet below measuring point (bmp). Depth of well and screened interval are in feet below land surface. Altitude of measuring point: Water levels in wells are usually reported as depths below land surface, although the measuring point can be any convenient fixed place near the top of the well. For these wells and piezometers, the measuring points are marked points on the tops of well casings - they vary from being near the land surface to a few feet above land surface. The altitude of the measuring point is commonly recorded so that static water levels also can be reported as altitudes. Abbreviations: USGS, U.S. Geological Survey; VOC, volatile organic compound; ft, foot; in., inch; -, not measured]

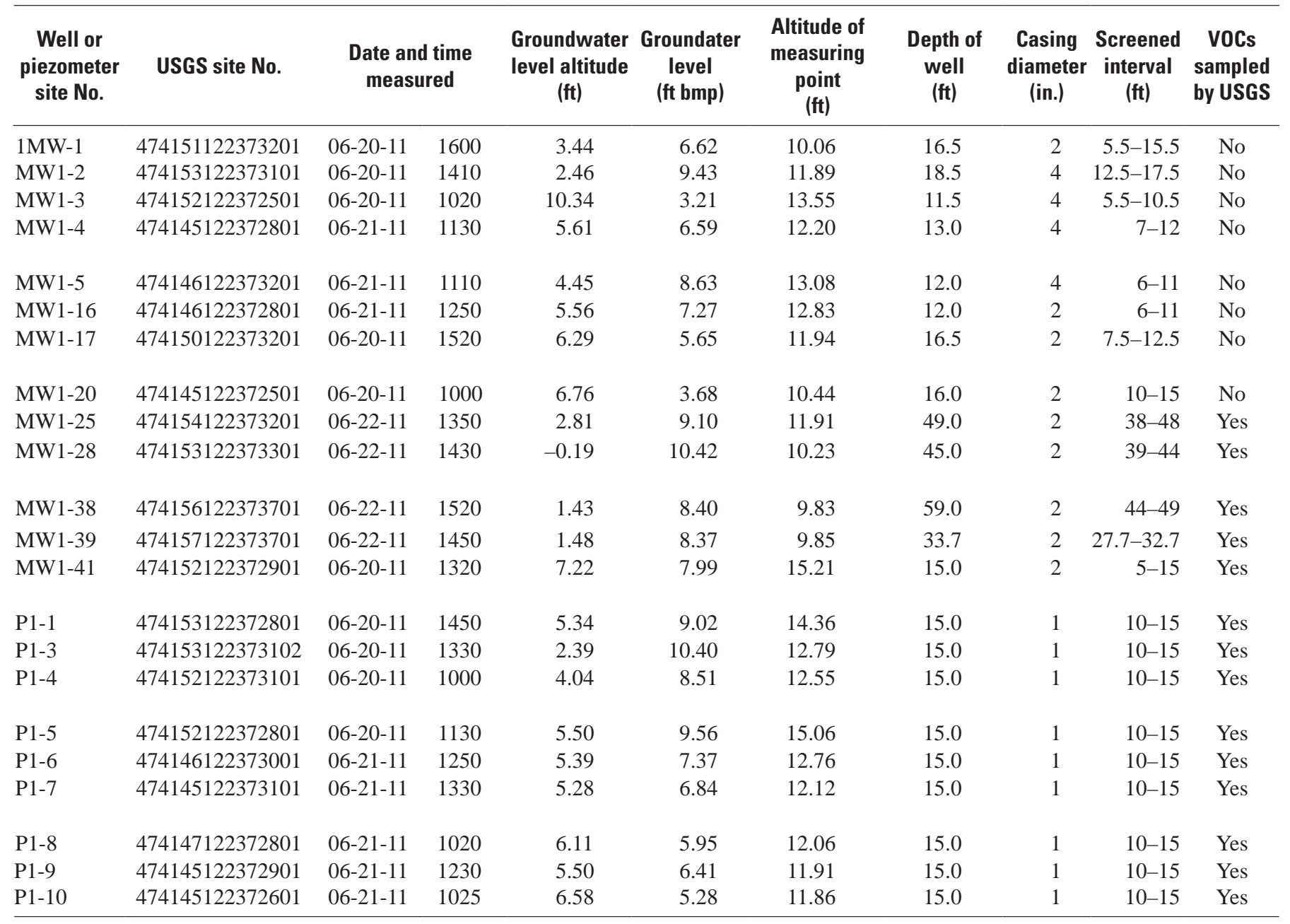




\section{Sample Collection and Analysis}

Water-level measurements and sample collection, processing, and field analyses during 2011 were in accordance with applicable USGS procedures as described in the National Field Manual (U.S. Geological Survey, variously dated). Redox-sensitive analyte measurements and concentrations that were determined for samples from 13 wells and 9 piezometers included dissolved hydrogen $\left(\mathrm{H}_{2}\right)$, dissolved oxygen (DO), filtered organic carbon (referred to as dissolved organic carbon, DOC), filtered nitrate plus nitrite, filtered manganese, filtered ferrous iron (iron (II)), filtered sulfate, unfiltered sulfide, dissolved methane, dissolved carbon dioxide, $\mathrm{pH}$, specific conductance, and filtered chloride. Concentrations of CVOCs were determined for samples from 5 of the 13 wells and from all 9 piezometers. Complete VOC analytical results (including data qualifiers) are available from the USGS National Water Information System (U.S. Geological Survey, 2012). Concentrations of dissolved gases ethane, ethene, and methane also were determined for samples from all 13 wells and 9 piezometers.

After measuring depth to water, all well and piezometer samples were collected with a peristaltic pump and single-use polyethylene tubing. Samples were collected after about three casing-volumes of water were purged from the wells and after allowing field measurements of $\mathrm{pH}$, specific conductance, and DO to stabilize to within 0.1 unit, 3 percent, and $0.3 \mathrm{mg} / \mathrm{L}$, respectively. Field measurements were monitored using a flow-through chamber and a Yellow Springs Instruments $\left(\mathrm{YSI}^{\circledR}\right)$ 600XLM or $6920 \mathrm{~V} 2$ data sonde. The sonde was calibrated prior to use as described in the National Field Manual (U.S. Geological Survey, variously dated, chaps. A6 and A8). The specific conductance sensor was calibrated daily with standard reference solutions $(1,000 \mu \mathrm{S} / \mathrm{cm}$ and checked with solutions ranging from 250 to $750 \mu \mathrm{S} / \mathrm{cm}$ ); the $\mathrm{pH}$ sensor was calibrated daily with two $\mathrm{pH}$ standards (7 and 10 and checked against $\mathrm{pH} 4$ buffer solution); and the DO sensor was calibrated daily using the air-saturated water method and occasionally verified with zero-DO solution. Dissolvedoxygen analyses were confirmed for most samples using 0 to $1 \mathrm{mg} / \mathrm{L}$ CHEMets Rhodazine- $\mathrm{D}^{\circledR}$ colorimetric vacuum ampoules (manufactured by CHEMetrics ${ }^{\circledR}$, Inc., Calverton, Virginia).

Concentrations of iron (II) were measured in field samples filtered through a $0.45-\mu \mathrm{m}$ membrane filter using a colorimetric 1,10-phenanthroline indicator method and a Hach Model 2010 spectrophotometer following Hach Method 8146 (Hach Company, 1998; adapted from American Public Health Association, 1980). Sulfide concentrations were measured in the field with a colorimetric methylene-blue indicator method immediately after collection by spectrophotometer, according to Hach Method 8131 (Hach Company, 1998; procedure is equivalent to U.S. Environmental Protection Agency method 376.2 [U.S. Environmental Protection Agency, 1983]). Dissolved carbon dioxide $\left(\mathrm{CO}_{2}\right)$ concentrations were measured in the field using Titret ${ }^{\circledR}$-Sodium hydroxide titrant with a $\mathrm{pH}$ indicator (manufactured by CHEMetrics ${ }^{\circledR}$, Inc., Calverton, Virginia).

Samples for analysis of dissolved $\mathrm{H}_{2}$ in ground water were collected after at least 30 minutes of stripping using the bubble-strip method of Chapelle and others (1997) and sent to Microseeps ${ }^{\circledR}$, Inc., Pittsburgh, Pennsylvania. In previous years, samples for $\mathrm{H}_{2}$ in groundwater were collected using the similar bubble-strip method, and concentrations were measured in the field using a reduction gas analyzer (Trace Analytical model E-001) (Dinicola and Huffman, 2012). The advantage of the field method was that samples were collected and analyzed at about 5-minute intervals, after the initial 20 minutes of stripping, until consecutive $\mathrm{H}_{2}$ concentrations stabilized to within 10 percent, a process that often required 1 hour or more. Because of aging equipment and lack of personnel to run the analyzer, a decision was made to ship the samples to Microseeps ${ }^{\odot}$, Inc., where only one sample per site was analyzed. This one sample may not be representative of the dissolved $\mathrm{H}_{2}$ within the sample because it is undetermined if there was enough equilibration time within the bubble to account for proper stripping of dissolved gases.

Samples for analysis of nitrate plus nitrite, sulfate, and chloride concentrations were filtered through a $0.45-\mu \mathrm{m}$ membrane filter into polyethylene bottles, chilled, and sent to the USGS National Water Quality Laboratory (NWQL) in Lakewood, Colorado. Chloride and sulfate were analyzed using ion chromatography as described by Fishman and Friedman (1989). Nitrate plus nitrite were analyzed colorimetrically by cadmium reduction and diazotization as described by Fishman (1993). The results for the nitrate plus nitrite analyses are referred to simply as "nitrate" in this report because nitrite was not detected at the site (Dinicola and others, 2002). Samples for analysis of manganese were filtered into an acid-rinsed bottle, acidified in the field with nitric acid to a pH of less than 2 and then shipped to the NWQL for analysis by inductively coupled plasma as described by Fishman (1993).

Samples for DOC analysis were filtered through a $0.45-\mu \mathrm{m}$ filter into amber glass bottles, acidified in the field with sulfuric acid to a $\mathrm{pH}$ of less than 2, chilled to less than $4^{\circ} \mathrm{C}$, and shipped to the NWQL. Organic carbon concentrations were determined using persulfate oxidation as described by Brenton and Arnett (1993).

Samples for VOC analysis were collected in pre-acidified 40-mL glass vials, placed on ice, and shipped to the NWQL for subsequent analysis using purge and trap capillarycolumn gas chromatography/mass spectrometry as described by Connor and others (1998). Samples for analysis of ethane, ethene, and methane were collected in pre-acidified 40-mL glass vials, placed on ice, and shipped to Test America Laboratories in Denver, Colorado, for subsequent analysis using gas chromatography with a flame-ionization detector according to USEPA Method RSK SOP-175 (U.S. Environmental Protection Agency, 1994; Kampbell and Vandegrift, 1998). 
Quality assurance and control of geochemical and contaminant sampling included collecting two duplicate samples for selected redox-sensitive analytes and VOCs, and analyzing a field blank sample for VOCs and redox-sensitive analytes. No substantial quality issues were identified in those samples (appendix A). Three duplicate samples for $\mathrm{H}_{2}$ concentrations were collected - two were split samples from the same gas bubble allowed to equilibrate for 30 minutes and one duplicate sample was from a separate gas bubble allowed to equilibrate for 30 minutes.

The different analytical techniques used to determine concentrations of dissolved $\mathrm{H}_{2}$ between this year (laboratory samples) and previous years (field samples) did not achieve similar results. The substantial difference in dissolved $\mathrm{H}_{2}-$ ranging from 2 to 20 times greater concentrations in 2011 than in 2010 (table 2, at back of report) and previous years-is a concern; however, it is unknown whether this difference is because of different analytical techniques. The $2011 \mathrm{H}_{2}$ data are outliers and do not accurately reflect the $\mathrm{H}_{2}$ concentrations in groundwater beneath the landfill. Therefore, the 2011 data are currently qualified as rejected until the differences between the two analytical techniques have been further investigated. The $\mathrm{H}_{2}$ data are further summarized in section, "Quality Assurance" in appendix A.

\section{Selected Monitoring Data}

The groundwater chemistry data are grouped with regard to aquifer and location of the well or piezometer. Upgradient sites are the two upper aquifer wells (MW1-3 and MW1-20) located east of the former landfill. The former upgradient intermediate aquifer well (MW1-33) located south of the landfill was decommissioned and can no longer be sampled. Northern plantation sites are all in the upper aquifer and include four wells (1MW-1, MW1-2, MW1-17, and MW1-41) and four piezometers (P1-1, P1-3, P1-4, and P1-5) in or near the northern phytoremediation plantation; piezometer P1-2 generally is dry during June and has never been sampled. Southern plantation sites also are all in the upper aquifer and include three wells (MW1-4, MW1-5, and MW1-16) and five piezometers (P1-6, P1-7, P1-8, P1-9, and P1-10) in or near the southern phytoremediation plantation. Intermediate aquifer sites include four wells (MW1-25, MW1-28, MW1-38, and MW1-39) that are downgradient of the landfill; no intermediate aquifer wells are in the footprint of the former landfill.

\section{Geochemical Data}

Geochemical data collected by the USGS from piezometers and selected wells at OU 1 from 1996 to 2011 are shown in table 2. Historical geochemical data for wells not sampled in 2011 are not included in table 2, but are available in Dinicola (2003, 2004, 2006) and Dinicola and Huffman
(2004, 2006, 2007, 2009, 2012). Overall, concentrations of oxidation-reduction (redox) sensitive constituents measured in 2011 were consistent with previous years, with dissolvedoxygen concentrations all at $0.4 \mathrm{mg} / \mathrm{L}$ or less; little to no detectable nitrate; abundant dissolved manganese, iron, and methane; and commonly detected sulfide.

Concentrations of reduced geochemicals (manganese, iron, sulfide, and methane) in the upgradient wells (MW1-3 and MW1-20) in 2011 were within the range of concentrations measured $(0.1-0.2 \mathrm{mg} / \mathrm{L})$ in previous years. The well upgradient from the northern plantation (MW1-3) continued to be characterized by low dissolvedoxygen concentrations $(0.1 \mathrm{mg} / \mathrm{L})$ and measureable nitrate concentrations $(0.64 \mathrm{mg} / \mathrm{L})$. The well upgradient from the southern plantation (MW1-20) continued to have low dissolved-oxygen concentrations $(0.3 \mathrm{mg} / \mathrm{L})$ and measurable dissolved manganese $(0.13 \mathrm{mg} / \mathrm{L})$ and iron (II) concentrations $(0.01 \mathrm{mg} / \mathrm{L})$.

Concentrations of geochemicals in the upper aquifer beneath the northern plantation in 2011 were consistent with concentrations measured in previous years, although some concentrations were slightly higher or lower than the range of concentrations measured in previous years. Dissolved-oxygen concentrations were $0.4 \mathrm{mg} / \mathrm{L}$ or less, and concentrations of manganese, iron, and methane were greater than those concentrations in upgradient groundwater. DOC concentrations ranged from 6.5 (well MW1-2) to $19 \mathrm{mg} / \mathrm{L}$ (well MW1-41 and piezometer P1-3), and were similar to concentrations measured in 2010. Methane concentrations ranged from 0.58 (well MW1-2) to $12 \mathrm{mg} / \mathrm{L}$ (piezometer P1-1), and were lower than concentrations measured in 2010. Concentrations of geochemicals in the upper aquifer beneath the southern plantation in 2011 also were consistent with concentrations measured in previous years, again with some concentrations slightly higher or lower than the range of concentrations measured in previous years. Dissolved-oxygen concentrations were $0.3 \mathrm{mg} / \mathrm{L}$ or less, DOC ranged from 2.2 (piezometer P1-6) to $16 \mathrm{mg} / \mathrm{L}$ (well MW1-16), and concentrations generally were greater than those concentrations in upgradient groundwater. Methane concentrations ranged from 1.0 (piezometer P1-6) to $6.4 \mathrm{mg} / \mathrm{L}$ (piezometer P1-8). These concentrations were lower than those of the northern plantation and commonly were less than concentrations measured 2010.

For the intermediate aquifer, concentrations of redox-sensitive constituents in 2011 were consistent with concentrations measured in previous years. One notable difference was that filtered chloride and sulfate concentrations at well MW1-28 (78 and $5.8 \mathrm{mg} / \mathrm{L}$, respectively) were substantially lower in 2011 than in previous years. Dissolvedoxygen concentrations in all intermediate aquifer wells downgradient of the landfill were less than $0.3 \mathrm{mg} / \mathrm{L}$, and DOC concentrations ranged from 2.1 to $7.2 \mathrm{mg} / \mathrm{L}$. Methane concentrations in these wells ranged from 0.85 to $2.6 \mathrm{mg} / \mathrm{L}$ and were highest in well MW1-25. 


\section{Volatile Organic Compounds}

VOCs and dissolved ethane and ethene data collected from piezometers and selected intermediate aquifer wells at OU 1 from June 1999 to June 2011 are shown in table 3 (at back of report). Chemical concentrations are reported as less than the reporting level for samples in which the analyte was neither identified nor detected at concentrations equal to or greater than the reporting level. Historical VOC data for wells not sampled in 2011 and for dates before 1999 are not included in table 3. Complete analytical results for the USGS data for 2011 and previous years are available from the USGS National Water Information System web site (U.S. Geological Survey, 2012; or Dinicola and others (2002), Dinicola (2003, 2004, 2006), Dinicola and Huffman (2004, 2006, 2007, 2009, 2012), and Huffman and Dinicola (2011). Complete analytical results for the complimentary U.S. Navy VOC data from 1995 through 2011 are available in U.S. Navy (2012). The total CVOC concentrations calculated for each sample is the sum of concentrations of CVOCs that were positively detected; concentrations reported as "less than" values were not included in the total.

\section{Volatile Organic Compound Concentrations beneath the Phytoremediation Plantations}

In the upper aquifer of the northern plantation in 2011, CVOC concentrations at most wells and piezometers were similar or slightly less than concentrations of CVOCs measured in previous years. In 2011, CVOCs were detected only in samples from piezometer P1-4. Total CVOC concentrations at piezometer P1-4 continue to be higher than concentrations measured in all other piezometers in the northern plantation, but were slightly lower in 2011 compared to previous years. Vinyl chloride concentrations were the lowest to date, measuring $192 \mu \mathrm{g} / \mathrm{L}$. In all wells and piezometers sampled, the concentrations of the reductive dechlorination byproducts ethane and ethene in 2011 were slightly lower or the same as concentrations measured in 2010 , ranging from less than 5.0 to $50 \mu \mathrm{g} / \mathrm{L}$.

For the southern plantation in 2011, CVOC concentrations measured in most wells and piezometers continued to be extremely high and variable from year to year. In 2011, total CVOC concentrations ranged from not detected to as high a $44,000 \mu \mathrm{g} / \mathrm{L}$, and concentrations increased in two of the five piezometers (P1-8 and P1-9). Concentrations at P1-8 increased by a factor of thirty to $9,900 \mu \mathrm{g} / \mathrm{L} 2011$, a sharp contrast to the relatively low concentrations observed from 2003 to 2010. At piezometer P1-9, the total CVOC concentration increased from $9,500 \mu \mathrm{g} / \mathrm{L}$ in 2010 to 44,000 $\mu \mathrm{g} / \mathrm{L}$ in 2011. Total CVOC concentrations decreased by 69 percent in piezometers P1-6 and P1-10 from 2010 to 2011. At piezometer $\mathrm{P} 1-7$, the total CVOC concentration decreased by 35 percent in 2011 compared to 2010 (28,000 and 42,300 $\mu \mathrm{g} / \mathrm{L}$, respectively). Since data collection began in 1999, the total CVOC concentrations in samples from piezometers P1-7 and P1-9 remain high and have been the highest measured in all wells in the southern and northern plantations. In 2011, one or both of the reductive dechlorination byproducts ethane and ethene were detected in three of the four wells and all piezometers in the southern plantation.

\section{Volatile Organic Compound Concentrations in the Intermediate Aquifer}

For the intermediate aquifer in 2011, total CVOC concentrations in wells MW1-25 and MW1-28 were consistent with previous years, with vinyl chloride concentrations remaining relatively high in both wells $(150$ and $590 \mu \mathrm{g} / \mathrm{L}$, respectively). At well MW1-39, farthest downgradient in the intermediate aquifer, low concentrations of cis-DCE and $\mathrm{VC}$ were detected $(0.6$ and $1.8 \mu \mathrm{g} / \mathrm{L}$, respectively), similar to concentrations measured in previous years. The sum of estimated concentrations of reductive dechlorination byproducts ethane and ethene decreased in 2011 at wells MW1-25 and MW1-28 to 11 and $20 \mu \mathrm{g} / \mathrm{L}$, respectively. Concentrations of ethane and ethene were not detected farther downgradient in the intermediate aquifer at wells MW1-38 and MW1-39.

\section{Summary}

Previous investigations report that natural attenuation and biodegradation of chlorinated volatile organic compounds (VOCs) are substantial in groundwater beneath the 9-acre former landfill at Operable Unit 1 (OU 1), Naval Undersea Warfare Center, Division Keyport, Washington. Phytoremediation combined with ongoing natural attenuation processes was the preferred remedy selected by the U.S. Navy, as specified in the Record of Decision for the site, and the U.S. Navy planted two hybrid poplar plantations on the landfill in spring 1999 to remove and to control the migration of chlorinated VOCs in shallow groundwater. The U.S. Geological Survey (USGS) has continued to monitor groundwater geochemistry to ensure that conditions remain favorable for contaminant biodegradation as specified in the Record of Decision. This report presents groundwater geochemical and selected VOC data collected at OU 1 by the USGS during June 20-22, 2011, in support of long-term monitoring for natural attenuation.

In the upper aquifer beneath the northern plantation, concentrations of manganese, iron, and methane were higher than concentrations in upgradient groundwater and were relatively high in comparison to concentrations in samples from the southern plantation and the intermediate aquifer. Anoxic conditions existed in all wells and piezometers, which is consistent with samples from previous years. Dissolved organic carbon concentrations ranged from 6.5 (well MW1-2) to 19 milligrams per liter $(\mathrm{mg} / \mathrm{L}$ ) (piezometer P1-3 and well MW1-41). Methane concentrations ranged from 0.58 (well MW1-2) to $12 \mathrm{mg} / \mathrm{L}$ (piezometer P1-1). 
For the southern plantation in 2011, chlorinated VOC concentrations measured in piezometers were often extremely high and varied widely spatially and temporally. At piezometer P1-9, the total chlorinated VOC concentration in samples increased from 9,500 micrograms per liter $(\mu \mathrm{g} / \mathrm{L})$ in 2010 to $44,000 \mu \mathrm{g} / \mathrm{L}$ in 2011 . Total chlorinated VOC concentrations increased by a factor of 30 in piezometer P1-8, but decreased as much as 69 percent in piezometers P1-6 and P1-10. Methane concentrations ranged from 1.0 (piezometer P1-6) to $6.4 \mathrm{mg} / \mathrm{L}$ (piezometer P1-8) and commonly were less than concentrations measured at northern plantation wells and piezometers.

Methane concentrations at most upper aquifer wells and piezometers beneath the landfill have been consistently higher than those measured in upgradient wells and organic carbon concentrations were similar to those measured in 2010. All intermediate aquifer wells downgradient of the landfill have been consistently anoxic. Methane concentrations in these wells ranged from 0.85 to $2.6 \mathrm{mg} / \mathrm{L}$ and were highest in well MW1-25. Total chlorinated VOC concentrations in wells MW1-25, MW1-28, and MW1-39 were consistent with previous years, with vinyl chloride concentrations remaining high with $150 \mu \mathrm{g} / \mathrm{L}$ at MW1-25 and $590 \mu \mathrm{g} / \mathrm{L}$ at MW-28. No detectable concentrations of chlorinated volatile organic compounds were measured at well MW1-38, farthest downgradient in the intermediate aquifer.

\section{References Cited}

American Public Health Association, 1980, Standard methods for the examination of water and wastewater (15th ed.): Washington, D.C., American Public Health Association.

Bradley, P.M., Landmeyer, J.E., and Dinicola, R.S., 1998, Anaerobic oxidation of $\left[1,2-{ }^{14} \mathrm{C}\right]$ dichloroethene under $\mathrm{Mn}(\mathrm{IV})-$ reducing conditions: Applied and Environmental Microbiology, v. 64, no. 4, p. 1560-1562.

Brenton, R.W., and Arnett, T.L., 1993, Methods of analysis by the U.S. Geological Survey National Water Quality Laboratory_Determination of dissolved organic carbon by UV-promoted persulfate oxidation and infrared spectrometry: U.S. Geological Survey Open-File Report 92-480, 12 p. (Also available at http://pubs.er.usgs.gov/ publication/ofr92480.)

Chapelle, F.H., Vroblesky, D.A., Woodward, J.C., and Lovely, D.R., 1997, Practical considerations for measuring hydrogen concentrations in groundwater: Environmental Science and Technology, v. 31, no. 10, p. 2,873-2,877.

CH2M Hill Constructors, Inc., 2002, 2001 annual reportOperable Unit 1, Area 1, former base landfill, Naval Undersea Warfare Center Division, Keyport, Washington: Prepared under Contract Task Order 0062 for Engineering Field Activity, Northwest, Naval Facilities Engineering Command, Poulsbo, Wash.
CH2M Hill Constructors, Inc., 2003, 2002 annual reportOperable Unit 1, Area 1, former base landfill, Naval Undersea Warfare Center Division, Keyport, Washington: Prepared under Contract Task Order 0062 for Engineering Field Activity, Northwest, Naval Facilities Engineering Command, Poulsbo, Wash.

CH2M Hill Constructors, Inc., 2004, 2003 annual reportOperable Unit 1, Area 1, former base landfill, Naval Undersea Warfare Center Division, Keyport, Washington: Prepared under Contract Task Order 0062 for Engineering Field Activity, Northwest, Naval Facilities Engineering Command, Poulsbo, Wash.

CH2M Hill Constructors, Inc., 2005, Draft 2004 annual report-Operable Unit 1, Area 1, former base landfill, Naval Undersea Warfare Center Division, Keyport, Washington: Prepared under Contract Task Order 0062 for Engineering Field Activity, Northwest, Naval Facilities Engineering Command, Poulsbo, Wash.

Connor, B.F., Rose, D.L, Noriega, L.M, and Abney, S.R., 1998, Methods of analysis by the U.S. Geological Survey National Water Quality Laboratory-Determination of 86 volatile organic compounds in water by gas chromatography-mass spectrometry, including detections less than reporting limits: U.S. Geological Survey OpenFile Report 97-829, 78 p. (Also available at http://pubs. er.usgs.gov/publication/ofr97829.)

Dinicola, R.S., 2003, Selected natural attenuation monitoring data, Operable Unit 1, Naval Undersea Warfare Center, Division Keyport, Washington, June 2001: U.S. Geological Survey Open-File Report 2003-344, 17 p. (Also available at http://pubs.er.usgs.gov/publication/ofr03344.)

Dinicola, R.S., 2004, Selected natural attenuation monitoring data, Operable Unit 1, Naval Undersea Warfare Center, Division Keyport, Washington, June 2002: U.S. Geological Survey Open-File Report 2004-1203, 19 p. (Also available at http://pubs.er.usgs.gov/publication/ofr20041203.)

Dinicola, R.S., 2006, Continued biodegradation of chlorethene compounds in ground water at Operable Unit 1, Naval Undersea Warfare Center, Division Keyport, Washington: U.S. Geological Survey Scientific Investigations Report 2006-5056, 42 p. (Also available at http://pubs.er.usgs.gov/ publication/sir20065056.)

Dinicola, R.S., Cox, S.E., Landmeyer, J.E., and Bradley, P.M., 2002, Natural attenuation of chlorinated volatile organic compounds in ground water at Operable Unit 1, Naval Undersea Weapons Center, Division Keyport, Washington: U.S. Geological Survey Water-Resources Investigations Report 2002-4119, 116 p. (Also available at http://pubs. er.usgs.gov/publication/wri024119.) 
Dinicola, R.S., and Huffman, R.L., 2004, Selected natural attenuation monitoring data, Operable Unit 1, Naval Undersea Warfare Center, Division Keyport, Washington, June 2003: U.S. Geological Survey Open-File Report 2004-1330, 19 p. (Also available at http://pubs.er.usgs.gov/ publication/ofr20041330.)

Dinicola, R.S., and Huffman, R.L., 2006, Selected natural attenuation monitoring data, Operable Unit 1, Naval Undersea Warfare Center, Division Keyport, Washington, June 2005: U.S. Geological Survey Open-File Report 2006-1374, 28 p. (Also available at http://pubs.er.usgs.gov/ publication/ofr20061374.)

Dinicola, R.S., and Huffman, R.L., 2007, Selected natural attenuation monitoring data, Operable Unit 1, Naval Undersea Warfare Center, Division Keyport, Washington, June 2006: U.S. Geological Survey Open-File Report 2007-1430, 30 p. (Also available at http://pubs.er.usgs.gov/ publication/ofr20071430.)

Dinicola, R.S., and Huffman, R.L., 2009, Selected natural attenuation monitoring data, Operable Unit 1, Naval Undersea Warfare Center, Division Keyport, Washington, 2007 and 2008: U.S. Geological Survey Open-File Report 2009-1141, 42 p. (Also available at http://pubs.er.usgs.gov/ publication/ofr20091141.)

Dinicola, R.S., and Huffman, R.L., 2012, Biodegradation of cholorethene compounds in groundwater at Operable Unit 1, Naval Undersea Warfare Center, Division Keyport, Washington, 1999-2010: U.S. Geological Survey Scientific Investigations Report 2012-5013, 56 p. (Also available at http://pubs.er.usgs.gov/publication/sir20125013.)

Fishman, M.J., ed., 1993, Methods of analysis by the U.S. Geological Survey National Water Quality LaboratoryDetermination of inorganic and organic constituents in water and fluvial sediments: U.S. Geological Survey OpenFile Report 93-125, 217 p. (Also available at http://pubs. er.usgs.gov/publication/ofr93125.)

Fishman, M.J., and Friedman, L.C., eds., 1989, Methods for determination of inorganic substances in water and fluvial sediments: U.S. Geological Survey Techniques of WaterResources Investigations, book 5, chap. A1, 545 p. (Also available at http://pubs.er.usgs.gov/publication/twri05A1.)

Hach Company, 1998, DR/2010 Spectrophotometer Procedures Manual: Loveland, Colo., Hach Company.

Huffman, R.L., and Dinicola, R.S., 2011, Groundwater geochemical and selected volatile organic compound data, Operable Unit 1, Naval Undersea Warfare Center, Division Keyport, Washington, June 2009: U.S. Geological Survey Data Series Report 644, 38 p. (Also available at http://pubs. er.usgs.gov/publication/ds644.)
Kampbell, D.H., and Vandergrift, S.A., 1998, Analysis of dissolved methane, ethane, ethenes, and propanes: Environmental Science and Technology, v. 23. no. 8, p. 965-969.

URS Consultants, Inc.,1997, Final summary data assessment report for Operable Unit 1 Naval Undersea Warfare Center Division Keyport, Washington: Prepared by URS Consultants, Seattle, Wash., under Contract Task Order 0189 for Engineering Field Activity, Northwest, Naval Facilities Engineering Command, Poulsbo, Wash., 3 volumes.

URS Consultants, Inc., 1998, Final record of decision for Operable Unit 1 Naval Undersea Warfare Center, Division Keyport, Washington: Prepared by URS Consultants, Seattle, Wash., for Engineering Field Activity, Northwest, Naval Facilities Engineering Command, Poulsbo, Wash., 111p.

URS Greiner, Inc., 1999, Phytoremediation closure report for Operable Unit 1, Naval Undersea Warfare Center, Division Keyport, Washington: Prepared by URS Greiner, Inc., Seattle, Wash., under Contract Task Order 0189 for Engineering Field Activity, Northwest, Naval Facilities Engineering Command, Poulsbo, Wash.

U.S. Environmental Protection Agency, 1983, Methods for chemical analysis of water and wastes - Office of Research chemical analysis of water and wastes: Washington, D.C., Office of Research and Development Report EPA 600/4-79020, $552 \mathrm{p}$.

U.S. Environmental Protection Agency, 1994, RSKSOP 175 rev. no. 2, Sample preparations and calculations for dissolved gas analysis in water samples using a GC headspace equilibration technique: U.S. Environmental Protection Agency Test Methods, Region 1, 14 p., accessed September 10, 2012, at http://www.epa.gov/region1/info/ testmethods/pdfs/RSKsop175v2.pdf.

U.S. Geological Survey, 2012, Water quality samples for Washington: National Water Information System web interface, accessed September 10, 2012, at http://nwis. waterdata.usgs.gov/wa/nwis/qwdat.

U.S. Geological Survey, variously dated, National field manual for the collection of water-quality data: U.S. Geological Survey Techniques of Water-Resources Investigations, book 9, chaps. A1-A9, accessed September 10, 2012, at http:// pubs.er.usgs.gov/publication/twri09.

U.S. Navy, 2012, Final spring 2011 long-term monitoring report, Area 1Operable Unit 1, Naval Base Kitsap Keyport, Washington: Contract No. N44255-09-D-4005, LTM/O/ Task Order 30. 


\section{Appendix A. Quality Assurance and Control of U.S. Geological Survey 2011 Geochemical Sampling}

Quality assurance and control of geochemical sampling included collecting duplicate and field blank samples for selected redox-sensitive analytes and volatile organic compounds (VOCs). The field blank was collected by pumping inorganic blank water and VOC-free water through clean tubing to determine possible sampling contamination. Complete laboratory quality assurance and control data from Test America Laboratories are on file with the U.S. Geological Survey (USGS) Washington Water Science Center in Tacoma, Washington.

Duplicate sample results compared favorably for all constituents, with the exception of dissolved hydrogen (table A1). A duplicate sample was collected and analyzed by the National Water Quality Laboratory (NWQL) for chlorinated VOCs, organic carbon, manganese, nitrate plus nitrite, sulfate and chloride for wells MW1-38 and MW1-41. The relative percent difference of duplicate results for these constituents agreed within 5.8 percent. Duplicate samples were collected and analyzed for VOCs by the NWQL and dissolved gases (ethane and ethene) by Test America Laboratories at wells MW1-38 and MW-41. No detectable concentrations of chlorinated volatile organic compounds or dissolved gasses were in the environmental or duplicate samples.

Duplicate samples for dissolved $\mathrm{H}_{2}$ were collected at wells MW1-25, MW1-38, and MW1-39, and were analyzed by Microseeps ${ }^{\circledR}$, Inc. At wells MW1-38 and MW1-39, duplicate split samples were collected from the same gas bubbles that had been allowed to equilibrate for 30 minutes. The relative percent difference for these concentrations ranged from 11 to 21 percent. At well MW1-25, a sequential duplicate sample was collected from a separate gas bubble that had been allowed to equilibrate for 30 minutes, with a relative percent difference of 58 percent. The high relative percent difference of these duplicate samples, as well as concentrations of $\mathrm{H}_{2}$ from environmental samples in 2011, were 2 to 20 times greater than concentrations measured in 2010-are an anomaly (table 2). It is not known if the resulting $\mathrm{H}_{2}$ concentrations are outliers due to different sampling and analysis techniques used in 2011 versus previous years, or if the large differences in $\mathrm{H}_{2}$ concentrations in 2011 represent $\mathrm{H}_{2}$ conditions in groundwater. Although the same sampling technique was used (bubble strip), the apparatus supplied by the analyzing laboratory was smaller than that used in previous years. Presumably a smaller volume would assume faster equilibration and stripping of gases into the bubble. However, only one volume of gas sample was taken for analysis, so full equilibration of stripped gases into the forming gas bubble was not confirmed as it had been with the sampling techniques used in previous years. Thus, the $\mathrm{H}_{2}$ concentration for 2011 will be qualified as rejected, until the differences between the two sampling and analysis techniques of the USGS field instrument and the Microseeps ${ }^{\odot}$, Inc. laboratory can be further investigated. For the 2012 annual sampling, the USGS will analyze $\mathrm{H}_{2}$ in the field and collect a subset of samples using the Microseeps ${ }^{\odot}$ sampling apparatus and laboratory to determine if the resulting data are comparable.

Filtered chloride was detected at an estimated concentrations of $0.11 \mathrm{mg} / \mathrm{L}$ in the blank sample collected at piezometer P1-8, which is small compared to filtered chloride concentrations in environmental samples that were measured at $3.4 \mathrm{mg} / \mathrm{L}$ or higher. Chloroethenes, chloroethanes, and BTEX (benzene, toluene, ethylbenzene, and xylene) compounds were not detected in the field blank sample. No changes were made to the dataset based on these quality control data. 
Table A1. Quality assurance data collected by the U.S. Geological Survey at Operable Unit 1, Naval Undersea Warfare Center, Division Keyport, Washington, 2011.

[Well or piezometer No.: D denotes duplicate sample; FB denotes field blank sample. Volatile organic compounds (VOCs): PCE, tetrachloroethene; TCE, trichloroethene; cis-DCE, cis-1,2-dichloroethene; trans-DCE, trans-1,2-dichloroethene; VC, vinyl chloride; TCA, 1,1,-trichloroethane; 1,1-DCA, 1,1-dichloroethane; 1,1-DCE, 1,1-dichloroethene; BTEX, benzene, toluene, ethylbezene, and xylene; CVOCs, sum of all chloroethenes and chloroethane concentrations shown in table. Abbreviations: $\mu \mathrm{g} / \mathrm{L}$, micrograms per liter; $\mathrm{mg} / \mathrm{L}$, milligrams per liter; ND, not detected. Symbols: <, actual value is less than the value shown; -, not analyzed]

\begin{tabular}{|c|c|c|c|c|c|c|c|c|c|c|c|c|}
\hline $\begin{array}{c}\text { Well or } \\
\text { piezometer } \\
\text { No. }\end{array}$ & $\begin{array}{c}\text { Date } \\
\text { sampled }\end{array}$ & $\begin{array}{c}\text { PCE } \\
(\mu \mathrm{g} / \mathrm{L})\end{array}$ & $\begin{array}{c}\text { TCE } \\
(\mu \mathrm{g} / \mathrm{L})\end{array}$ & $\begin{array}{c}\text { cis-DCE } \\
(\mu \mathrm{g} / \mathrm{L})\end{array}$ & \multicolumn{2}{|c|}{$\begin{array}{c}\text { trans-DCE } \\
(\mu \mathrm{g} / \mathrm{L})\end{array}$} & $\begin{array}{c}\text { VC } \\
(\mu \mathrm{g} / \mathrm{L})\end{array}$ & $\begin{array}{c}\text { Ethane } \\
(\mu \mathrm{g} / \mathrm{L})\end{array}$ & $\begin{array}{c}\text { Ethene } \\
\text { ( } \mu \mathrm{g} / \mathrm{L} \text { ) }\end{array}$ & $\begin{array}{c}\text { TCA } \\
(\mu g / L)\end{array}$ & $\begin{array}{c}\text { 1,1-DCA } \\
\text { ( } \mu \mathrm{g} / \mathrm{L})\end{array}$ & $\begin{array}{c}\text { 1,1-DCE } \\
\text { ( } \mu \mathrm{g} / \mathrm{L})\end{array}$ \\
\hline MW1-25 & $06-22-11$ & - & - & - & \multicolumn{2}{|c|}{-} & - & - & - & - & - & - \\
\hline MW1-25D & $06-22-11$ & - & - & - & \multicolumn{2}{|c|}{-} & - & - & - & - & - & - \\
\hline MW1-38 & $06-22-11$ & $<0.1$ & $<0.1$ & $<0.1$ & \multicolumn{2}{|c|}{$<0.1$} & $<0.2$ & $<5.0$ & $<5.0$ & $<0.1$ & $<0.1$ & $<0.1$ \\
\hline MW1-38D & 06-22-11 & $<.1$ & $<.1$ & $<.1$ & \multicolumn{2}{|c|}{$<.1$} & $<.2$ & $<5.0$ & $<5.0$ & $<.1$ & $<.1$ & $<.1$ \\
\hline MW1-39 & $06-22-11$ & - & - & - & \multicolumn{2}{|c|}{-} & - & - & - & - & - & - \\
\hline MW1-39D & $06-22-11$ & - & - & - & \multicolumn{2}{|c|}{-} & - & - & - & - & - & - \\
\hline MW1-41 & $06-20-11$ & $<.1$ & $<.1$ & .2 & \multicolumn{2}{|c|}{$<.1$} & $<.2$ & $<5.0$ & $<5.0$ & $<.1$ & $<.1$ & $<.1$ \\
\hline MW1D & $06-20-11$ & $<.1$ & $<.1$ & .2 & \multicolumn{2}{|c|}{$<.1$} & $<.2$ & $<5.0$ & $<5.0$ & $<.1$ & $<.1$ & $<.1$ \\
\hline P1-5FB & $06-20-11$ & $<.1$ & $<.1$ & $<.1$ & \multicolumn{2}{|c|}{$<.1$} & $<.2$ & $<5.0$ & $<5.0$ & $<.1$ & $<.1$ & $<.1$ \\
\hline \multirow[b]{2}{*}{$\begin{array}{c}\text { Well or } \\
\text { piezometer } \\
\text { No. }\end{array}$} & \multirow[b]{2}{*}{$\begin{array}{c}\text { Date } \\
\text { sampled }\end{array}$} & \multicolumn{2}{|c|}{ Total } & \multirow{2}{*}{\multicolumn{2}{|c|}{$\begin{array}{l}\text { Dissolved } \\
\text { hydrogen } \\
\text { (nM) }\end{array}$}} & \multirow{2}{*}{\multicolumn{2}{|c|}{$\begin{array}{c}\text { Filtered } \\
\text { (dissolved) } \\
\text { organic } \\
\text { carbon } \\
\text { (mg/L) } \\
\end{array}$}} & \multirow{2}{*}{$\begin{array}{c}\text { Filtered } \\
\mathrm{NO}_{2}+\mathrm{NO}_{3} \\
(\mathrm{mg} / \mathrm{L} \\
\text { as } \mathrm{N})\end{array}$} & \multirow{2}{*}{$\begin{array}{c}\text { Filtered } \\
\text { manga- } \\
\text { nese } \\
\text { (mg/L) }\end{array}$} & \multirow[b]{2}{*}{$\begin{array}{c}\text { Filtered } \\
\text { sulfate } \\
\text { (mg/L) }\end{array}$} & \multirow[b]{2}{*}{$\begin{array}{l}\text { Dissolved } \\
\text { methane } \\
\text { (mg/L) }\end{array}$} & \multirow[b]{2}{*}{$\begin{array}{c}\text { Filtered } \\
\text { chloride } \\
\text { (mg/L) }\end{array}$} \\
\hline & & $\begin{array}{l}\text { BTEX } \\
\text { ( } \mu \mathrm{g} / \mathrm{L})\end{array}$ & $\begin{array}{c}\text { CVOCs } \\
\text { ( } \mu \mathrm{g} / \mathrm{L})\end{array}$ & & & & & & & & & \\
\hline MW1-25 & 06-22-11 & - & - & & 1.2 & & .2 & $<0.02$ & 0.14 & 7.2 & 2.6 & 127 \\
\hline MW1-25D & $06-22-11$ & - & - & & 1.9 & & - & - & - & - & - & - \\
\hline MW1-38 & $06-22-11$ & ND & ND & & 1.8 & & .1 & $<.02$ & .05 & 1.6 & 0.85 & 198 \\
\hline MW1-38D & $06-22-11$ & ND & ND & & 1.6 & & 1 & $<.02$ & .05 & 1.6 & .9 & 197 \\
\hline MW1-39 & $06-22-11$ & - & - & & 2.4 & & 1 & $<.02$ & .01 & $<.09$ & 2.3 & 60.7 \\
\hline MW1-39D & $06-22-11$ & - & - & & 1.9 & & - & - & - & - & - & - \\
\hline MW1-41 & 06-20-11 & 0.3 & 0.2 & & 1.2 & 19 & & $<.02$ & 3.7 & $<.09$ & 11 & 13 \\
\hline MW1-41D & $06-20-11$ & .3 & .2 & & - & 18 & & $<.02$ & 3.6 & $<.09$ & 11 & 13 \\
\hline P1-5FB & 06-20-11 & ND & ND & & - & & .1 & $<.02$ & $<.2$ & $<.09$ & E.002 & $<.06$ \\
\hline
\end{tabular}


Table 2. Groundwater geochemical data collected at Operable Unit 1, Naval Undersea Warfare Center, Division Keyport, Washington, 1996-2011.

[All other data were published in Dinicola and others (2002), Dinicola (2003, 2004, 2006), Dinicola and Huffman (2004, 2006, 2007, 2009), and Dinicola and Huffman (2011); prior to 2000, bicarbonate was calculated from an unfiltered sample. Reported concentrations less than the detection limit usually are estimated. A range of dissolved hydrogen concentrations is shown when equilibration at a single value was never achieved. Well or piezometer No.: MW, monitoring well; P, piezometer. Abbreviations: $\mathrm{nM}$, nanomolar; $\mathrm{mg} / \mathrm{L}$, milligram per liter; $\mu \mathrm{S} / \mathrm{cm}$, microsiemens per centimeter at 25 degrees Celsius; ORP, oxidation-reduction potential; mV, millivolt. Symbols: E, estimated value; R, data rejected (selected 1996 dissolved-oxygen data were rejected because of inadequate well purging; selected 2002 dissolved-hydrogen data were rejected because of interference from downhole instruments, 2011, dissolved-hydrogen data were rejected pending further investigation between U.S. Geological Survey field analysis and analyzing laboratory); <, actual value is less than value shown; >, actual value is greater than value shown; -, not analyzed]

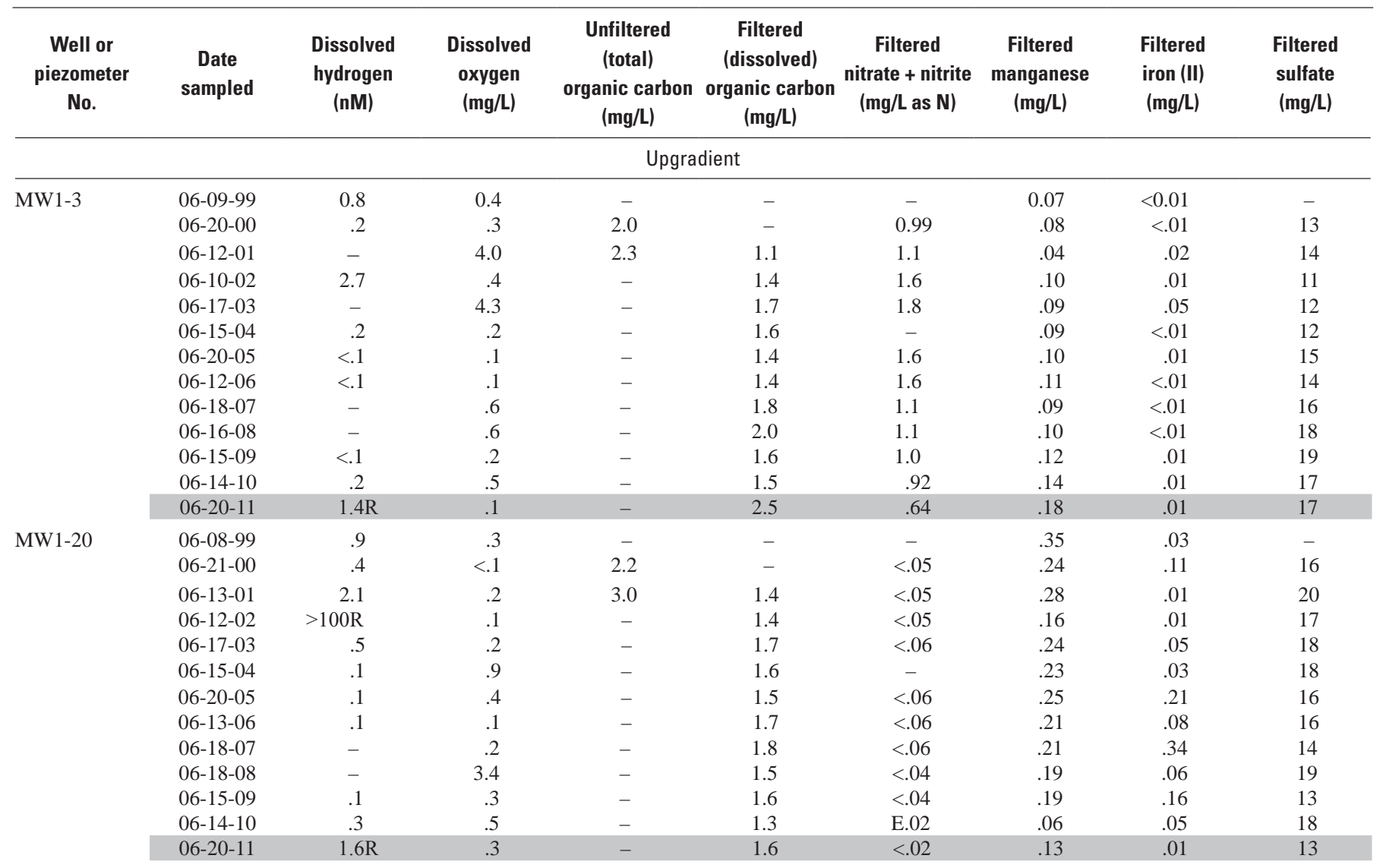


Table 2. Groundwater geochemical data collected at Operable Unit 1, Naval Undersea Warfare Center, Division Keyport, Washington, 1996-2011.-Continued

[All other data were published in Dinicola and others (2002), Dinicola (2003, 2004, 2006), Dinicola and Huffman (2004, 2006, 2007, 2009), and Dinicola and Huffman (2011); prior to 2000, bicarbonate was calculated from an unfiltered sample. Reported concentrations less than the detection limit usually are estimated. A range of dissolved hydrogen concentrations is shown when equilibration at a single value was never achieved. Well or piezometer No.: MW, monitoring well; P, piezometer. Abbreviations: nM, nanomolar; $\mathrm{mg} / \mathrm{L}$, milligram per liter; $\mu \mathrm{S} / \mathrm{cm}$, microsiemens per centimeter at 25 degrees Celsius; ORP, oxidation-reduction potential; mV, millivolt. Symbols: E, estimated value; R, data rejected (selected 1996 dissolved-oxygen data were rejected because of inadequate well purging; selected 2002 dissolved-hydrogen data were rejected because of interference from downhole instruments, 2011, dissolved-hydrogen data were rejected pending further investigation between U.S. Geological Survey field analysis and analyzing laboratory); <, actual value is less than value shown; >, actual value is greater than value shown; -, not analyzed]

\begin{tabular}{|c|c|c|c|c|c|c|c|c|c|}
\hline $\begin{array}{c}\text { Well or } \\
\text { piezometer No. }\end{array}$ & $\begin{array}{c}\text { Date } \\
\text { sampled }\end{array}$ & $\begin{array}{l}\text { Unfiltered } \\
\text { sulfide } \\
\text { (mg/L) }\end{array}$ & $\begin{array}{c}\text { Dissolved } \\
\text { methane } \\
\text { (mg/L) }\end{array}$ & $\begin{array}{c}\text { Dissolved } \\
\text { carbon } \\
\text { dioxide } \\
\text { (mg/L) }\end{array}$ & $\begin{array}{c}\text { Filtered } \\
\text { bicarbonate } \\
\text { (mg/L) }\end{array}$ & $\begin{array}{c}\mathrm{pH} \\
\text { (units) }\end{array}$ & $\begin{array}{c}\text { Specific } \\
\text { conduc- } \\
\text { tance } \\
(\mu \mathrm{S} / \mathrm{cm})\end{array}$ & $\begin{array}{l}\text { ORP } \\
(\mathrm{mV})\end{array}$ & $\begin{array}{c}\text { Filtered } \\
\text { chloride } \\
\text { (mg/L) }\end{array}$ \\
\hline \multicolumn{10}{|c|}{ Upgradient } \\
\hline \multirow[t]{8}{*}{ MW1-3 } & 06-09-99 & $<0.01$ & - & - & 81 & 6.0 & 202 & - & - \\
\hline & $06-20-00$ & $<.01$ & 0.02 & - & 82 & 5.9 & 205 & 180 & 8.4 \\
\hline & $06-17-03$ & - & .02 & 80 & - & 6.0 & 199 & 200 & 10 \\
\hline & 06-15-04 & $<.01$ & .01 & - & 73 & 5.7 & 205 & 195 & 9.1 \\
\hline & 06-20-05 & $<.01$ & - & $<50$ & - & 6.0 & 192 & - & 7.5 \\
\hline & $06-12-06$ & $<.01$ & .004 & 40 & - & 5.5 & 243 & 136 & 7.0 \\
\hline & 06-18-07 & .01 & - & 41 & - & 5.9 & 209 & - & 5.9 \\
\hline & $06-16-08$ & $<.01$ & - & 80 & - & 6.0 & 198 & 260 & 5.1 \\
\hline \multirow{12}{*}{ MW1-20 } & $06-21-00$ & $<.01$ & .01 & - & 240 & 6.8 & 530 & 79 & 14 \\
\hline & 06-13-01 & $<.01$ & .27 & - & 260 & 6.4 & 544 & 250 & 33 \\
\hline & 06-12-02 & $<.01$ & .06 & 97 & 250 & 7.0 & 701 & 180 & 29 \\
\hline & 06-17-03 & - & .09 & 90 & - & 6.3 & 491 & 290 & 32 \\
\hline & 06-15-04 & $<.01$ & .03 & - & 260 & 6.4 & 552 & 98 & 35 \\
\hline & 06-20-05 & $<.01$ & - & 80 & - & 6.3 & 520 & 87 & 28 \\
\hline & $06-13-06$ & $<.01$ & .03 & 60 & - & 6.3 & 574 & 70 & 31 \\
\hline & 06-18-07 & $<.01$ & - & 40 & - & 6.8 & 508 & 7.2 & 25 \\
\hline & 06-18-08 & - & - & 70 & - & 6.6 & 517 & 74 & 38 \\
\hline & 06-15-09 & $<.01$ & .05 & 45 & - & 6.5 & 481 & - & 24 \\
\hline & $06-14-10$ & $<.01$ & .03 & 35 & - & 6.9 & 580 & - & 43 \\
\hline & 06-20-11 & $<.01$ & .02 & 60 & - & 6.5 & 426 & - & 27 \\
\hline
\end{tabular}


Table 2. Groundwater geochemical data collected at Operable Unit 1, Naval Undersea Warfare Center, Division Keyport, Washington, 1996-2011.-Continued

[All other data were published in Dinicola and others (2002), Dinicola (2003, 2004, 2006), Dinicola and Huffman (2004, 2006, 2007, 2009), and Dinicola and Huffman (2011); prior to 2000, bicarbonate was calculated from an unfiltered sample. Reported concentrations less than the detection limit usually are estimated. A range of dissolved hydrogen concentrations is shown when equilibration at a single value was never achieved. Well or piezometer No.: MW, monitoring well; P, piezometer. Abbreviations: $\mathrm{nM}$, nanomolar; $\mathrm{mg} / \mathrm{L}$, milligram per liter; $\mu \mathrm{S} / \mathrm{cm}$, microsiemens per centimeter at 25 degrees Celsius; ORP, oxidation-reduction potential; mV, millivolt. Symbols: E, estimated value; R, data rejected (selected 1996 dissolved-oxygen data were rejected because of inadequate well purging; selected 2002 dissolved-hydrogen data were rejected because of interference from downhole instruments, 2011, dissolved-hydrogen data were rejected pending further investigation between U.S. Geological Survey field analysis and analyzing laboratory); <, actual value is less than value shown; >, actual value is greater than value shown; -, not analyzed]

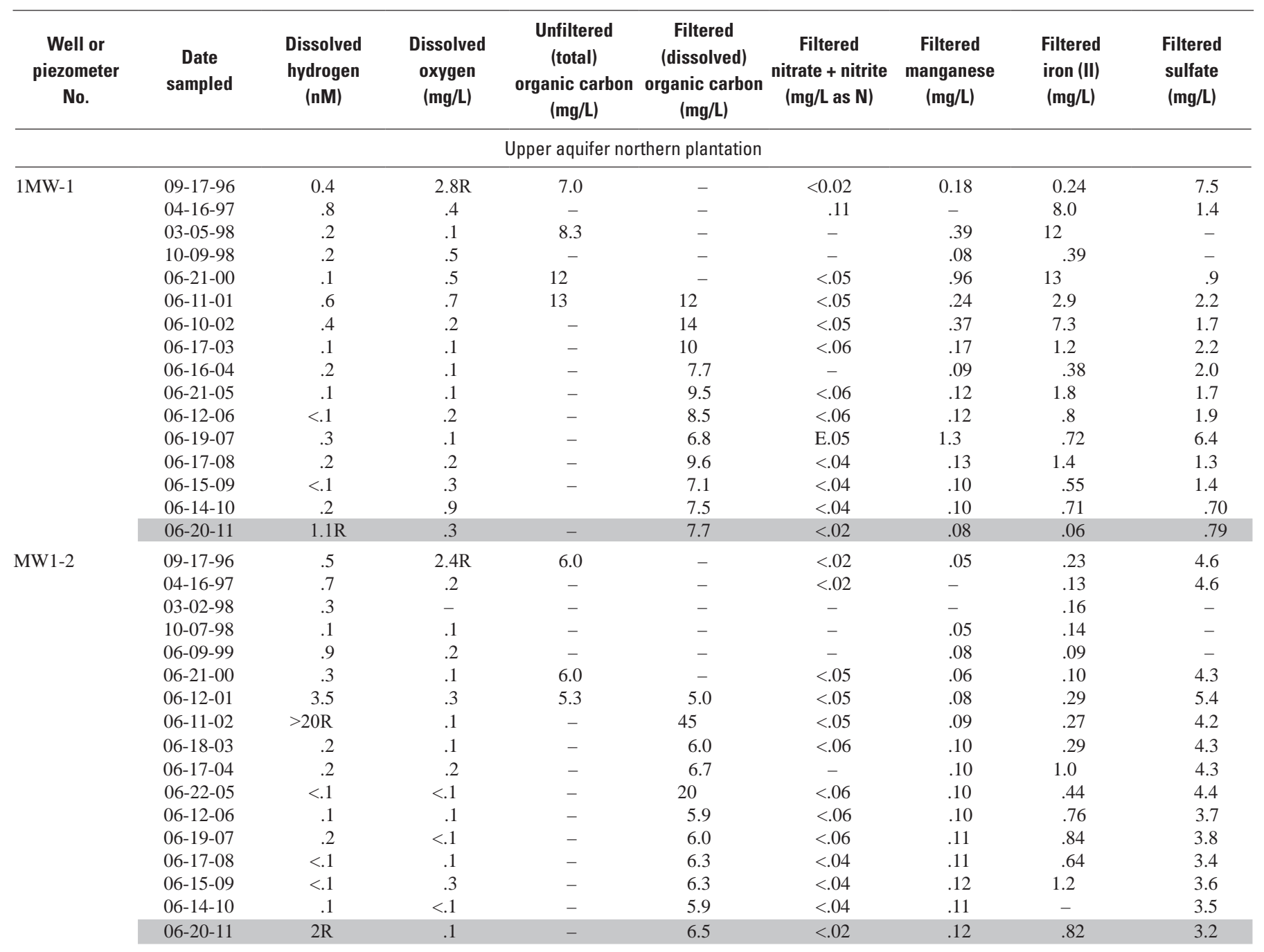


Table 2. Groundwater geochemical data collected at Operable Unit 1, Naval Undersea Warfare Center, Division Keyport, Washington, 1996-2011.-Continued

[All other data were published in Dinicola and others (2002), Dinicola (2003, 2004, 2006), Dinicola and Huffman (2004, 2006, 2007, 2009), and Dinicola and Huffman (2011); prior to 2000, bicarbonate was calculated from an unfiltered sample. Reported concentrations less than the detection limit usually are estimated. A range of dissolved hydrogen concentrations is shown when equilibration at a single value was never achieved. Well or piezometer No.: MW, monitoring well; P, piezometer. Abbreviations: nM, nanomolar; $\mathrm{mg} / \mathrm{L}$, milligram per liter; $\mu \mathrm{S} / \mathrm{cm}$, microsiemens per centimeter at 25 degrees Celsius; ORP, oxidation-reduction potential; mV, millivolt. Symbols: E, estimated value; R, data rejected (selected 1996 dissolved-oxygen data were rejected because of inadequate well purging; selected 2002 dissolved-hydrogen data were rejected because of interference from downhole instruments, 2011, dissolved-hydrogen data were rejected pending further investigation between U.S. Geological Survey field analysis and analyzing laboratory); <, actual value is less than value shown; >, actual value is greater than value shown; -, not analyzed]

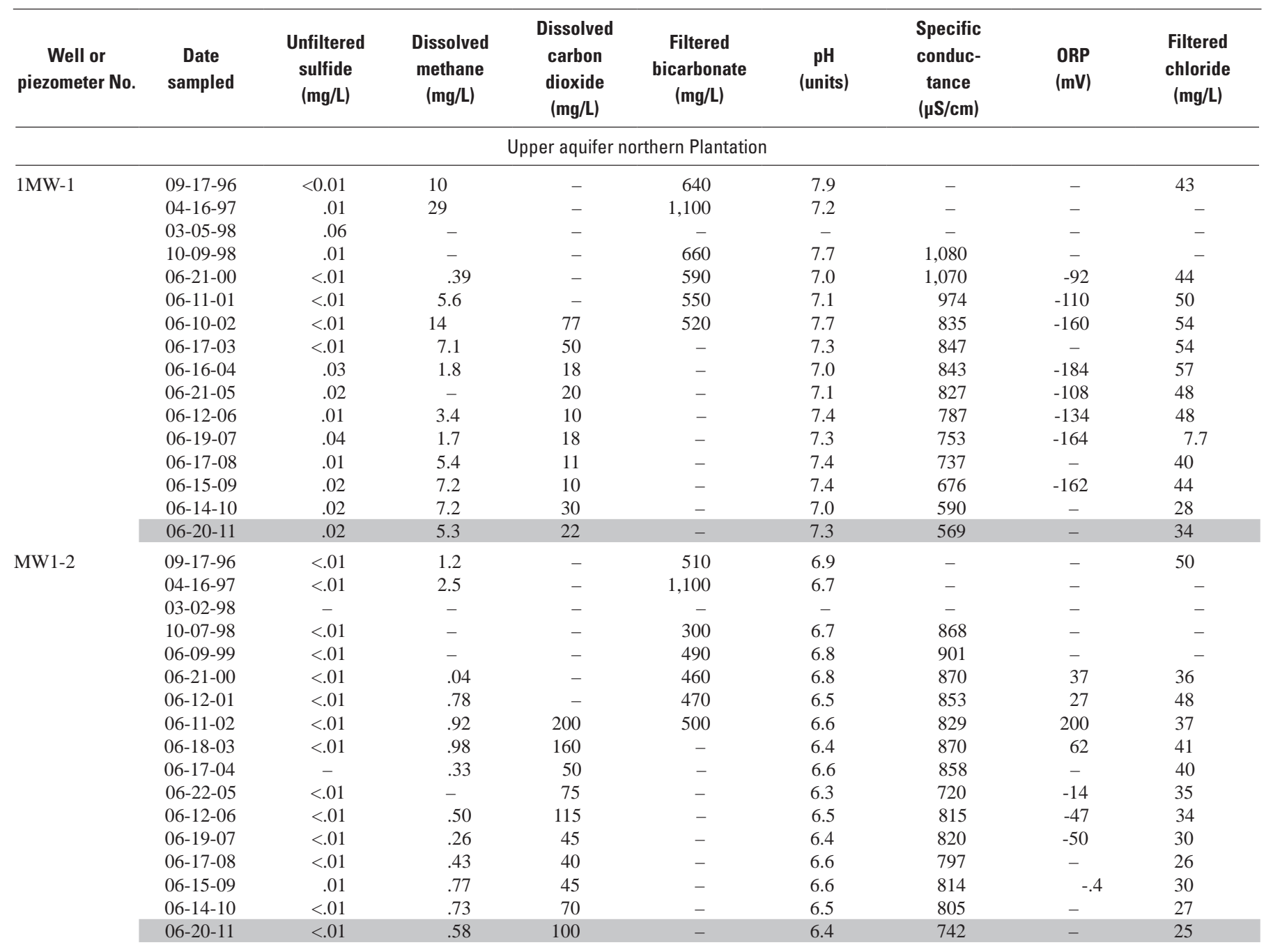


Table 2. Groundwater geochemical data collected at Operable Unit 1, Naval Undersea Warfare Center, Division Keyport, Washington, 1996-2011.-Continued

[All other data were published in Dinicola and others (2002), Dinicola (2003, 2004, 2006), Dinicola and Huffman (2004, 2006, 2007, 2009), and Dinicola and Huffman (2011); prior to 2000, bicarbonate was calculated from an unfiltered sample. Reported concentrations less than the detection limit usually are estimated. A range of dissolved hydrogen concentrations is shown when equilibration at a single value was never achieved. Well or piezometer No.: MW, monitoring well; P, piezometer. Abbreviations: $\mathrm{nM}$, nanomolar; $\mathrm{mg} / \mathrm{L}$, milligram per liter; $\mu \mathrm{S} / \mathrm{cm}$, microsiemens per centimeter at 25 degrees Celsius; ORP, oxidation-reduction potential; mV, millivolt. Symbols: E, estimated value; R, data rejected (selected 1996 dissolved-oxygen data were rejected because of inadequate well purging; selected 2002 dissolved-hydrogen data were rejected because of interference from downhole instruments, 2011, dissolved-hydrogen data were rejected pending further investigation between U.S. Geological Survey field analysis and analyzing laboratory); <, actual value is less than value shown; >, actual value is greater than value shown; -, not analyzed]

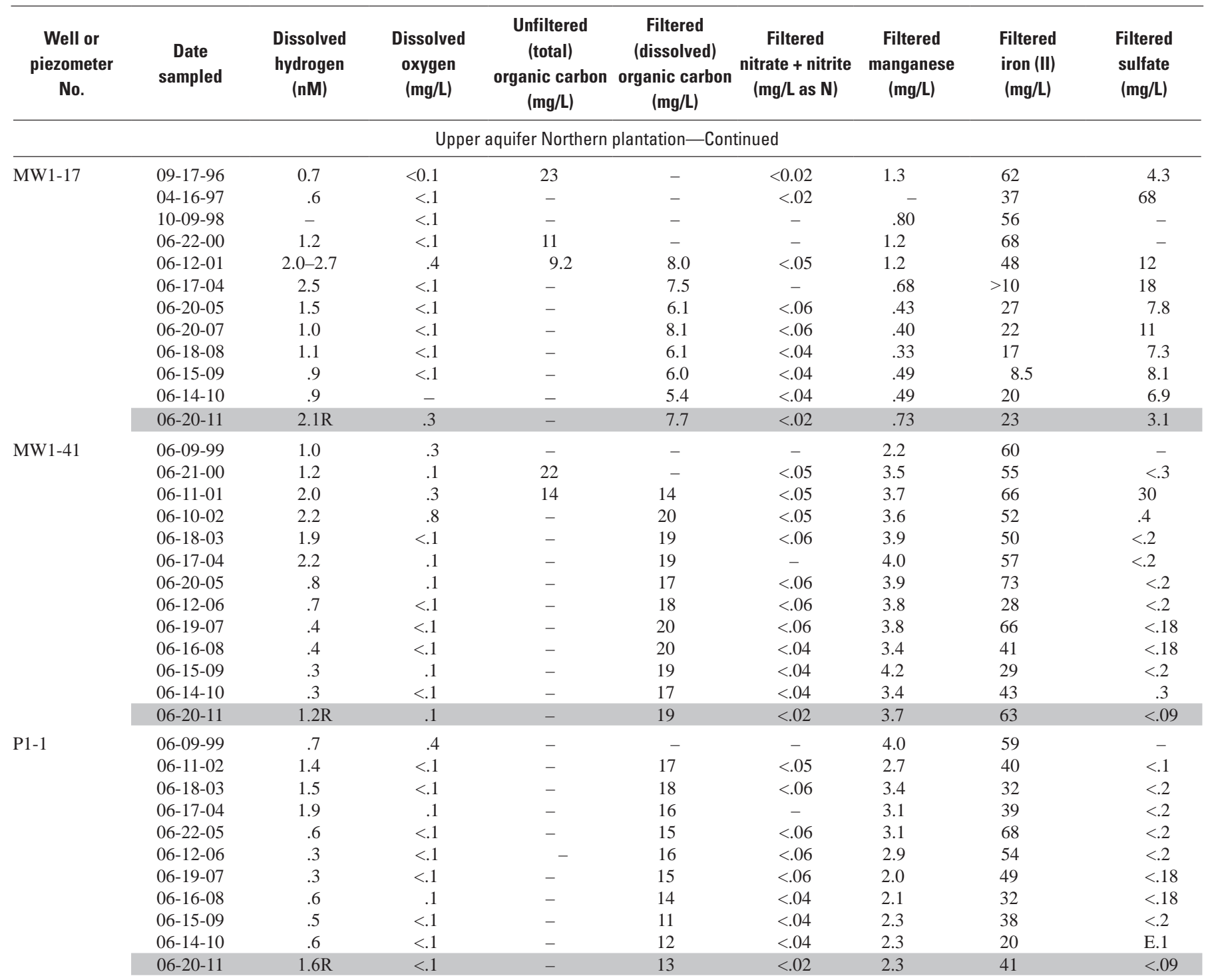


Table 2. Groundwater geochemical data collected at Operable Unit 1, Naval Undersea Warfare Center, Division Keyport, Washington, 1996-2011.-Continued

[All other data were published in Dinicola and others (2002), Dinicola (2003, 2004, 2006), Dinicola and Huffman (2004, 2006, 2007, 2009), and Dinicola and Huffman (2011); prior to 2000, bicarbonate was calculated from an unfiltered sample. Reported concentrations less than the detection limit usually are estimated. A range of dissolved hydrogen concentrations is shown when equilibration at a single value was never achieved. Well or piezometer No.: MW, monitoring well; P, piezometer. Abbreviations: nM, nanomolar; $\mathrm{mg} / \mathrm{L}$, milligram per liter; $\mu \mathrm{S} / \mathrm{cm}$, microsiemens per centimeter at 25 degrees Celsius; ORP, oxidation-reduction potential; mV, millivolt. Symbols: E, estimated value; R, data rejected (selected 1996 dissolved-oxygen data were rejected because of inadequate well purging; selected 2002 dissolved-hydrogen data were rejected because of interference from downhole instruments, 2011, dissolved-hydrogen data were rejected pending further investigation between U.S. Geological Survey field analysis and analyzing laboratory); <, actual value is less than value shown; >, actual value is greater than value shown; -, not analyzed]

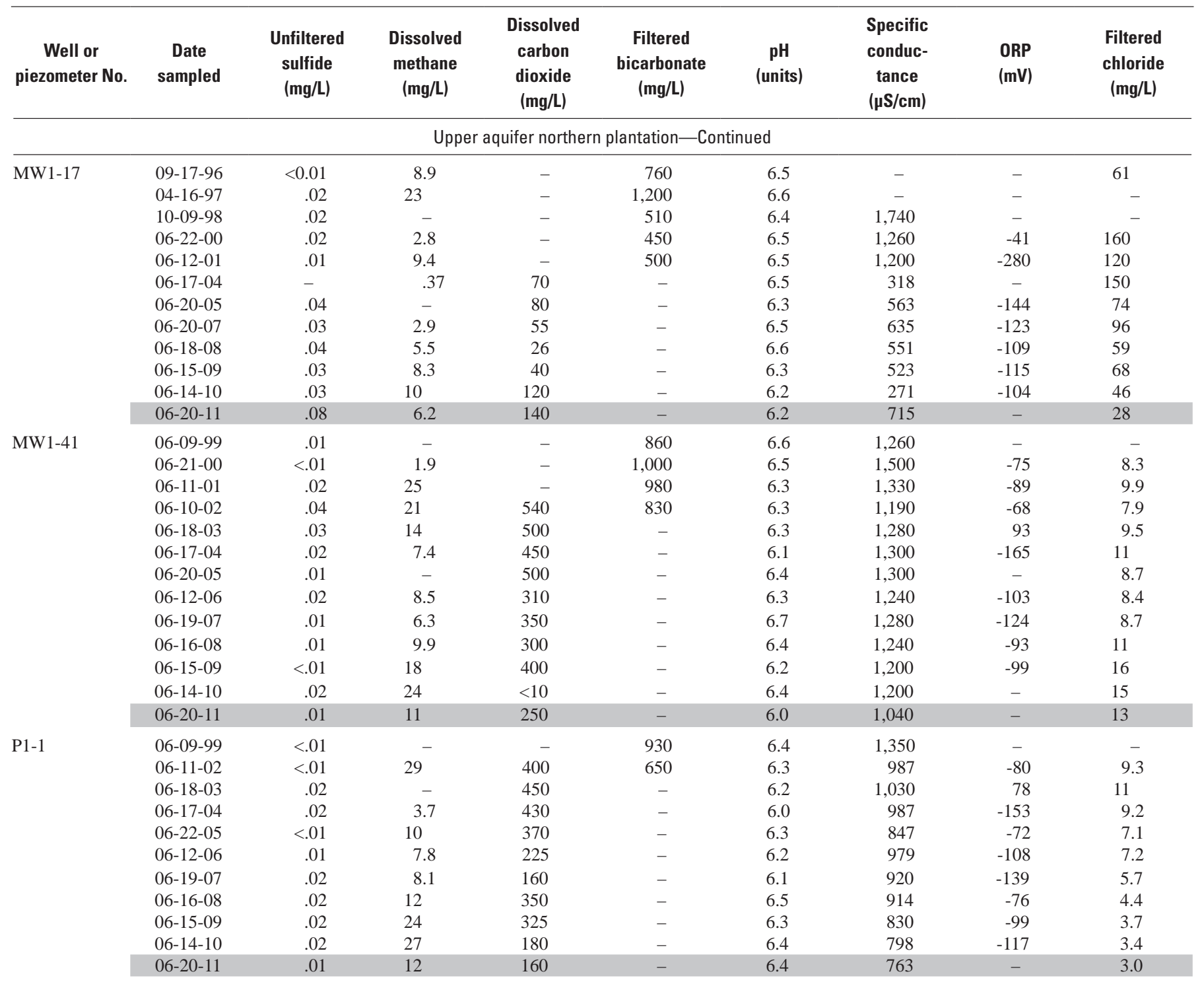


Table 2. Groundwater geochemical data collected at Operable Unit 1, Naval Undersea Warfare Center, Division Keyport, Washington, 1996-2011.-Continued

[All other data were published in Dinicola and others (2002), Dinicola (2003, 2004, 2006), Dinicola and Huffman (2004, 2006, 2007, 2009), and Dinicola and Huffman (2011); prior to 2000, bicarbonate was calculated from an unfiltered sample. Reported concentrations less than the detection limit usually are estimated. A range of dissolved hydrogen concentrations is shown when equilibration at a single value was never achieved. Well or piezometer No.: MW, monitoring well; P, piezometer. Abbreviations: $\mathrm{nM}$, nanomolar; $\mathrm{mg} / \mathrm{L}$, milligram per liter; $\mu \mathrm{S} / \mathrm{cm}$, microsiemens per centimeter at 25 degrees Celsius; ORP, oxidation-reduction potential; mV, millivolt. Symbols: E, estimated value; R, data rejected (selected 1996 dissolved-oxygen data were rejected because of inadequate well purging; selected 2002 dissolved-hydrogen data were rejected because of interference from downhole instruments, 2011, dissolved-hydrogen data were rejected pending further investigation between U.S. Geological Survey field analysis and analyzing laboratory); <, actual value is less than value shown; >, actual value is greater than value shown; -, not analyzed]

\begin{tabular}{|c|c|c|c|c|c|c|c|c|c|}
\hline $\begin{array}{c}\text { Well or } \\
\text { piezometer } \\
\text { No. }\end{array}$ & $\begin{array}{c}\text { Date } \\
\text { sampled }\end{array}$ & $\begin{array}{c}\text { Dissolved } \\
\text { hydrogen } \\
\text { (nM) }\end{array}$ & $\begin{array}{c}\text { Dissolved } \\
\text { oxygen } \\
\text { (mg/L) }\end{array}$ & $\begin{array}{c}\text { Unfiltered } \\
\text { (total) } \\
\text { organic carbon } \\
\text { (mg/L) }\end{array}$ & 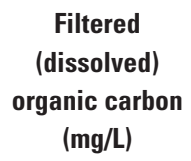 & $\begin{array}{c}\text { Filtered } \\
\text { nitrate + nitrite } \\
(\mathrm{mg} / \mathrm{L} \text { as } \mathrm{N})\end{array}$ & $\begin{array}{c}\text { Filtered } \\
\text { manganese } \\
(\mathrm{mg} / \mathrm{L})\end{array}$ & $\begin{array}{c}\text { Filtered } \\
\text { iron (II) } \\
(\mathrm{mg} / \mathrm{L})\end{array}$ & $\begin{array}{c}\text { Filtered } \\
\text { sulfate } \\
\text { (mg/L) }\end{array}$ \\
\hline \multicolumn{10}{|c|}{ Upper aquifer northern plantation-Continued } \\
\hline \multirow[t]{8}{*}{ P1-3 } & 06-09-99 & 0.4 & 0.2 & - & - & - & 1.0 & 19 & - \\
\hline & 06-11-02 & .3 & $<.1$ & - & 45 & $<0.05$ & 2.6 & 39 & 1.0 \\
\hline & 06-22-05 & .2 & $<.1$ & - & 20 & $<.06$ & 2.8 & 60 & .38 \\
\hline & $06-12-06$ & .2 & $<.1$ & - & 20 & $<.06$ & 2.5 & 39 & .2 \\
\hline & 06-19-07 & .3 & $<.1$ & - & 22 & $<.06$ & 2.5 & 40 & .24 \\
\hline & 06-17-08 & .9 & $<.1$ & - & 23 & $<.04$ & 2.9 & 32 & $<.18$ \\
\hline & 06-15-09 & .5 & .2 & - & 20 & $<.04$ & 3.0 & - & E.1 \\
\hline & $06-14-10$ & .4 & .2 & - & 19 & $<.04$ & 2.8 & 21 & .2 \\
\hline \multirow{9}{*}{ P1-4 } & 06-18-03 & .2 & .1 & - & 7.0 & $<.06$ & .43 & 4.1 & 4.0 \\
\hline & $06-17-04$ & .1 & .1 & - & 7.6 & - & .42 & 3.0 & 4.0 \\
\hline & 06-21-05 & .1 & .1 & - & 6.7 & $<.06$ & .38 & 2.3 & 4.6 \\
\hline & 06-12-06 & .1 & $<.1$ & - & 6.8 & $<.06$ & .35 & 1.8 & 4.3 \\
\hline & 06-19-07 & .3 & $<.1$ & - & 7.1 & $<.06$ & .35 & 3.2 & 4.7 \\
\hline & 06-16-08 & $<.1$ & $<.1$ & - & 7.7 & $<.04$ & .35 & 3.5 & 4.4 \\
\hline & 06-15-09 & $<.1$ & .6 & - & 7.5 & $<.04$ & .39 & 2.4 & 4.1 \\
\hline & 06-14-10 & .2 & .7 & - & 7.5 & $<.04$ & .38 & .12 & 4.4 \\
\hline & $06-20-11$ & $2.2 \mathrm{R}$ & $<.1$ & - & 8.5 & $<.02$ & .41 & 2.2 & 5.1 \\
\hline \multirow[t]{4}{*}{ P1-5 } & 06-08-99 & 3.0 & .3 & - & - & - & 3.1 & 72 & - \\
\hline & 06-10-02 & 1.7 & .1 & - & 25 & $<.05$ & 2.6 & 62 & $<.6$ \\
\hline & 06-18-03 & 2.2 & .1 & - & 24 & $<.06$ & 3.1 & 54 & $<.2$ \\
\hline & $06-17-04$ & 2.1 & $<.1$ & - & 23 & - & 3.1 & $>10$ & $<.2$ \\
\hline
\end{tabular}


Table 2. Groundwater geochemical data collected at Operable Unit 1, Naval Undersea Warfare Center, Division Keyport, Washington, 1996-2011.-Continued

[All other data were published in Dinicola and others (2002), Dinicola (2003, 2004, 2006), Dinicola and Huffman (2004, 2006, 2007, 2009), and Dinicola and Huffman (2011); prior to 2000, bicarbonate was calculated from an unfiltered sample. Reported concentrations less than the detection limit usually are estimated. A range of dissolved hydrogen concentrations is shown when equilibration at a single value was never achieved. Well or piezometer No.: MW, monitoring well; P, piezometer. Abbreviations: $\mathrm{nM}$, nanomolar; $\mathrm{mg} / \mathrm{L}$, milligram per liter; $\mu \mathrm{S} / \mathrm{cm}$, microsiemens per centimeter at 25 degrees Celsius; ORP, oxidation-reduction potential; mV, millivolt. Symbols: E, estimated value; R, data rejected (selected 1996 dissolved-oxygen data were rejected because of inadequate well purging; selected 2002 dissolved-hydrogen data were rejected because of interference from downhole instruments, 2011, dissolved-hydrogen data were rejected pending further investigation between U.S. Geological Survey field analysis and analyzing laboratory); <, actual value is less than value shown; >, actual value is greater than value shown; -, not analyzed]

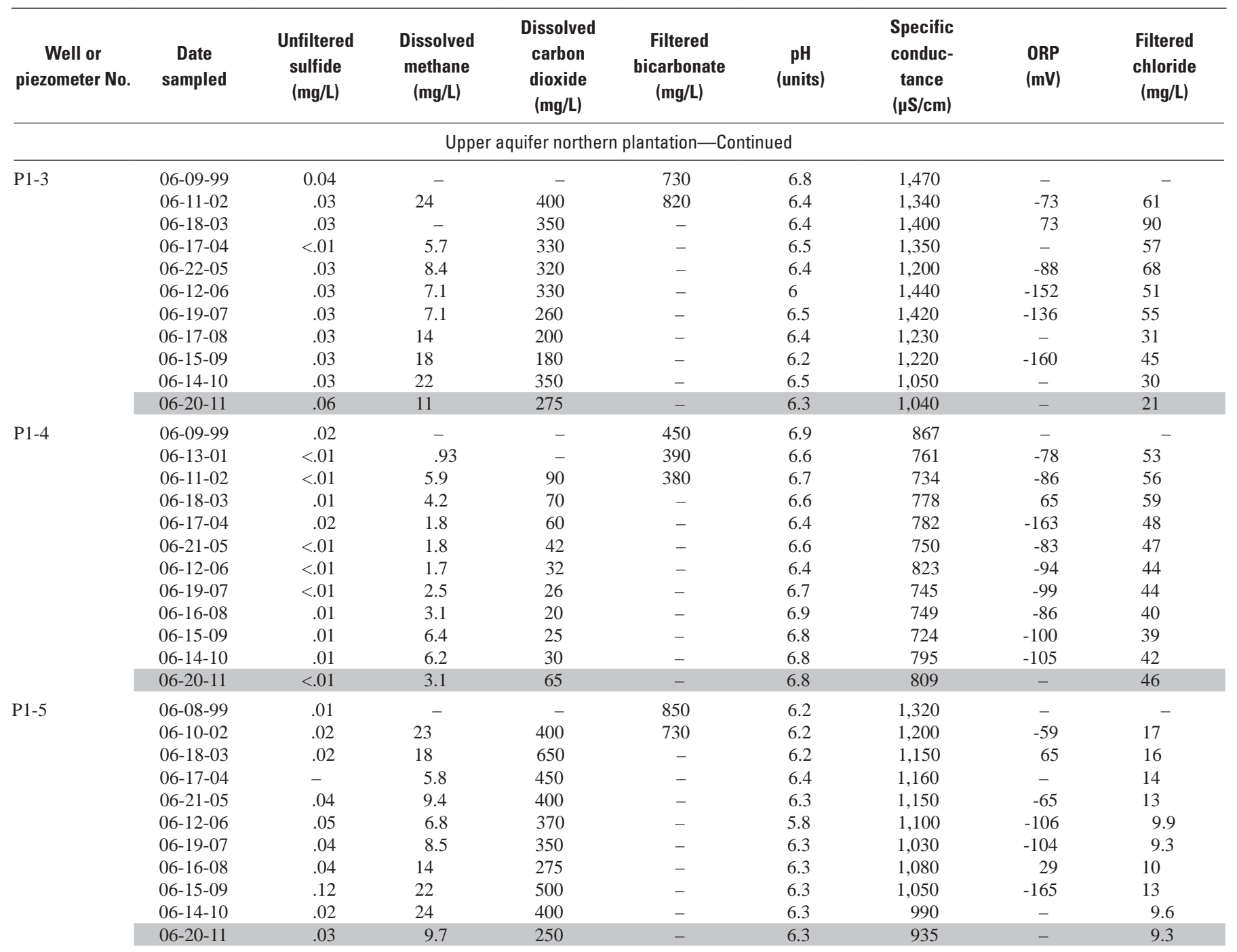


Table 2. Groundwater geochemical data collected at Operable Unit 1, Naval Undersea Warfare Center, Division Keyport, Washington, 1996-2011.-Continued

[All other data were published in Dinicola and others (2002), Dinicola (2003, 2004, 2006), Dinicola and Huffman (2004, 2006, 2007, 2009), and Dinicola and Huffman (2011); prior to 2000, bicarbonate was calculated from an unfiltered sample. Reported concentrations less than the detection limit usually are estimated. A range of dissolved hydrogen concentrations is shown when equilibration at a single value was never achieved. Well or piezometer No.: MW, monitoring well; P, piezometer. Abbreviations: $\mathrm{nM}$, nanomolar; $\mathrm{mg} / \mathrm{L}$, milligram per liter; $\mu \mathrm{S} / \mathrm{cm}$, microsiemens per centimeter at 25 degrees Celsius; ORP, oxidation-reduction potential; mV, millivolt. Symbols: E, estimated value; R, data rejected (selected 1996 dissolved-oxygen data were rejected because of inadequate well purging; selected 2002 dissolved-hydrogen data were rejected because of interference from downhole instruments, 2011, dissolved-hydrogen data were rejected pending further investigation between U.S. Geological Survey field analysis and analyzing laboratory); <, actual value is less than value shown; >, actual value is greater than value shown; -, not analyzed]

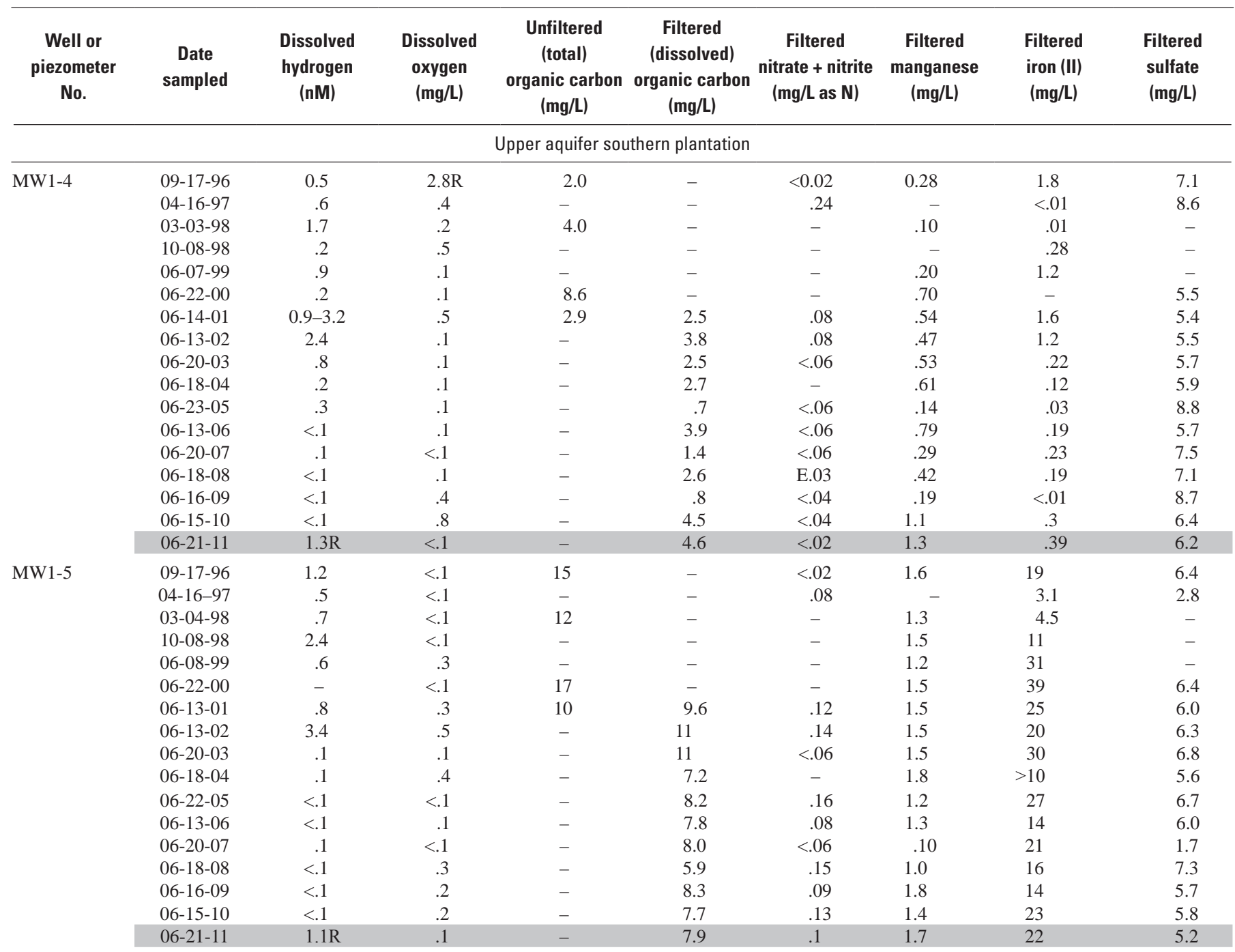


Table 2. Groundwater geochemical data collected at Operable Unit 1, Naval Undersea Warfare Center, Division Keyport, Washington, 1996-2011.-Continued

[All other data were published in Dinicola and others (2002), Dinicola (2003, 2004, 2006), Dinicola and Huffman (2004, 2006, 2007, 2009), and Dinicola and Huffman (2011); prior to 2000, bicarbonate was calculated from an unfiltered sample. Reported concentrations less than the detection limit usually are estimated. A range of dissolved hydrogen concentrations is shown when equilibration at a single value was never achieved. Well or piezometer No.: MW, monitoring well; P, piezometer. Abbreviations: nM, nanomolar; $\mathrm{mg} / \mathrm{L}$, milligram per liter; $\mu \mathrm{S} / \mathrm{cm}$, microsiemens per centimeter at 25 degrees Celsius; ORP, oxidation-reduction potential; mV, millivolt. Symbols: E, estimated value; R, data rejected (selected 1996 dissolved-oxygen data were rejected because of inadequate well purging; selected 2002 dissolved-hydrogen data were rejected because of interference from downhole instruments, 2011, dissolved-hydrogen data were rejected pending further investigation between U.S. Geological Survey field analysis and analyzing laboratory); <, actual value is less than value shown; >, actual value is greater than value shown; -, not analyzed]

\begin{tabular}{|c|c|c|c|c|c|c|c|c|c|}
\hline $\begin{array}{c}\text { Well or } \\
\text { piezometer No. }\end{array}$ & $\begin{array}{c}\text { Date } \\
\text { sampled }\end{array}$ & $\begin{array}{l}\text { Unfiltered } \\
\text { sulfide } \\
\text { (mg/L) }\end{array}$ & $\begin{array}{l}\text { Dissolved } \\
\text { methane } \\
\text { (mg/L) }\end{array}$ & $\begin{array}{c}\text { Dissolved } \\
\text { carbon } \\
\text { dioxide } \\
\text { (mg/L) }\end{array}$ & $\begin{array}{c}\text { Filtered } \\
\text { bicarbonate } \\
\text { (mg/L) }\end{array}$ & $\underset{\text { (units) }}{\mathrm{pH}}$ & $\begin{array}{c}\text { Specific } \\
\text { conduc- } \\
\text { tance } \\
(\mu \mathrm{S} / \mathrm{cm})\end{array}$ & $\begin{array}{l}\text { ORP } \\
(\mathrm{mV})\end{array}$ & $\begin{array}{c}\text { Filtered } \\
\text { chloride } \\
\text { (mg/L) }\end{array}$ \\
\hline \multicolumn{10}{|c|}{ Upper aquifer southern plantation } \\
\hline \multirow{10}{*}{ MW1-4 } & $09-17-96$ & $<0.01$ & 1.2 & - & 130 & 6.9 & - & - & 15 \\
\hline & $04-16-97$ & $<.01$ & .70 & - & 270 & 7.3 & - & - & - \\
\hline & 06-07-99 & $<.01$ & - & - & 180 & 6.6 & 350 & - & - \\
\hline & $06-22-00$ & $<.01$ & .56 & - & 230 & 6.8 & 412 & -26 & 19 \\
\hline & $06-14-01$ & $<.01$ & 3.7 & - & 180 & 6.5 & 360 & -8 & 22 \\
\hline & $06-13-02$ & $<.01$ & 5.2 & 60 & 190 & 6.6 & 442 & -14 & 20 \\
\hline & $06-20-03$ & $<.01$ & 3.7 & 40 & - & 6.7 & 324 & - & 17 \\
\hline & 06-18-04 & $<.01$ & 1.1 & 50 & - & 6.0 & 320 & 91 & 23 \\
\hline & $06-15-10$ & $<.01$ & 4.1 & 16 & - & 6.9 & 360 & - & 16 \\
\hline & 06-21-11 & $<.01$ & 2.9 & - & - & 6.9 & 325 & - & 17 \\
\hline \multirow[t]{11}{*}{ MW1-5 } & 09-17-96 & $<.01$ & 2.4 & - & 410 & 6.7 & - & - & 21 \\
\hline & 04-16-97 & .03 & 18 & - & 1,400 & 6.6 & - & - & - \\
\hline & $03-04-98$ & $<.01$ & - & - & - & - & - & - & - \\
\hline & $10-08-98$ & $<.01$ & - & - & 410 & 6.4 & 1,740 & - & - \\
\hline & 06-08-99 & .01 & - & - & 510 & 6.5 & 855 & - & - \\
\hline & $06-22-00$ & $<.01$ & 1.1 & - & 460 & 6.6 & 790 & -80 & 19 \\
\hline & 06-13-01 & .01 & 2.4 & - & 470 & 6.4 & 766 & -70 & 12 \\
\hline & $06-13-02$ & .02 & 7.4 & 180 & 740 & 6.5 & 608 & -77 & 9.6 \\
\hline & $06-20-03$ & .03 & 4.9 & 180 & - & 6.4 & 711 & - & 10 \\
\hline & 06-18-04 & - & 2.4 & 200 & - & 6.5 & 795 & - & 9.8 \\
\hline & $06-22-05$ & .02 & - & 70 & - & 6.3 & 520 & -95 & 9.5 \\
\hline
\end{tabular}


Table 2. Groundwater geochemical data collected at Operable Unit 1, Naval Undersea Warfare Center, Division Keyport, Washington, 1996-2011.-Continued

[All other data were published in Dinicola and others (2002), Dinicola (2003, 2004, 2006), Dinicola and Huffman (2004, 2006, 2007, 2009), and Dinicola and Huffman (2011); prior to 2000, bicarbonate was calculated from an unfiltered sample. Reported concentrations less than the detection limit usually are estimated. A range of dissolved hydrogen concentrations is shown when equilibration at a single value was never achieved. Well or piezometer No.: MW, monitoring well; P, piezometer. Abbreviations: $\mathrm{nM}$, nanomolar; $\mathrm{mg} / \mathrm{L}$, milligram per liter; $\mu \mathrm{S} / \mathrm{cm}$, microsiemens per centimeter at 25 degrees Celsius; ORP, oxidation-reduction potential; mV, millivolt. Symbols: E, estimated value; R, data rejected (selected 1996 dissolved-oxygen data were rejected because of inadequate well purging; selected 2002 dissolved-hydrogen data were rejected because of interference from downhole instruments, 2011, dissolved-hydrogen data were rejected pending further investigation between U.S. Geological Survey field analysis and analyzing laboratory); <, actual value is less than value shown; >, actual value is greater than value shown; -, not analyzed]

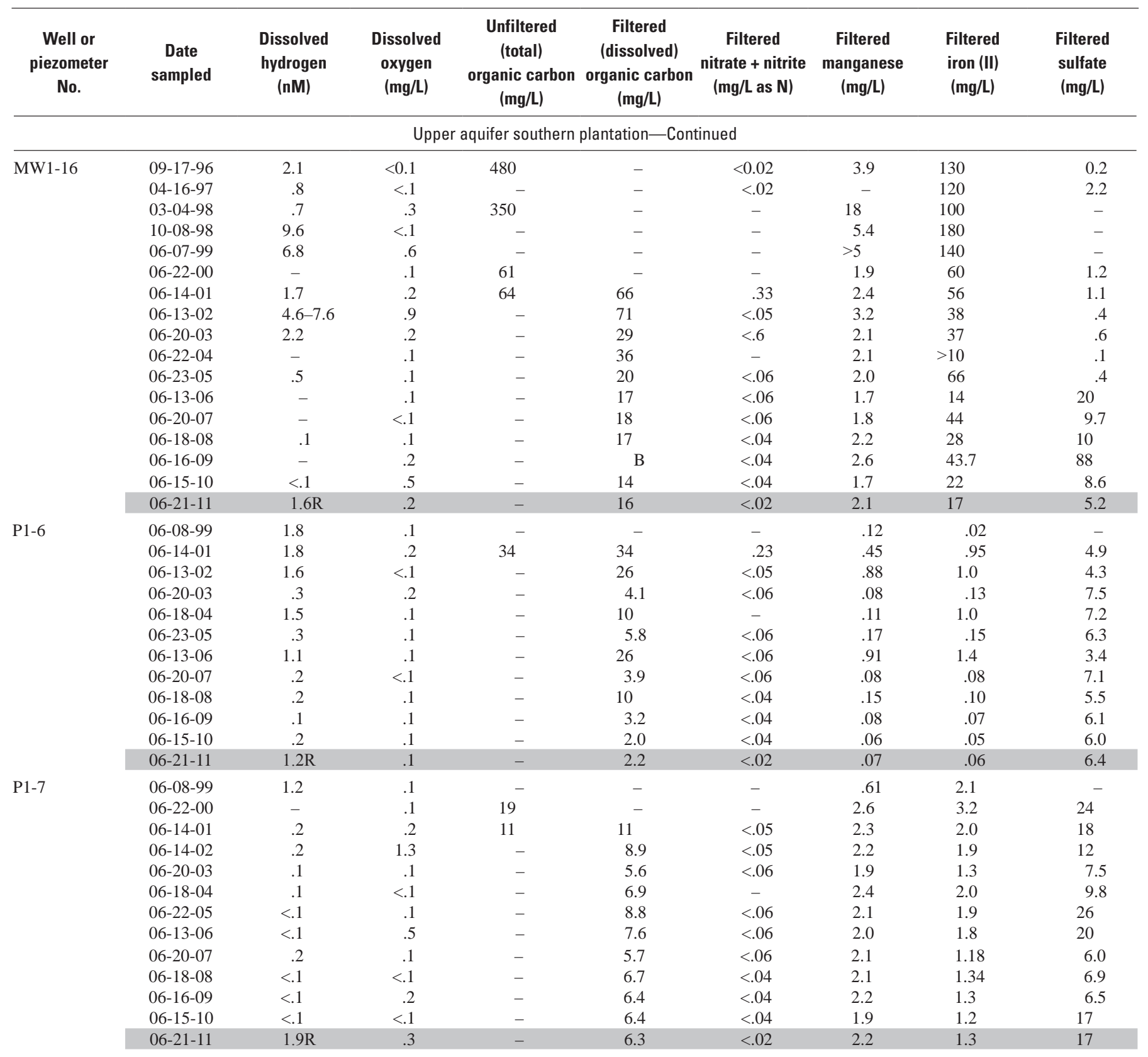


Table 2. Groundwater geochemical data collected at Operable Unit 1, Naval Undersea Warfare Center, Division Keyport, Washington, 1996-2011.-Continued

[All other data were published in Dinicola and others (2002), Dinicola (2003, 2004, 2006), Dinicola and Huffman (2004, 2006, 2007, 2009), and Dinicola and Huffman (2011); prior to 2000, bicarbonate was calculated from an unfiltered sample. Reported concentrations less than the detection limit usually are estimated. A range of dissolved hydrogen concentrations is shown when equilibration at a single value was never achieved. Well or piezometer No.: MW, monitoring well; P, piezometer. Abbreviations: nM, nanomolar; $\mathrm{mg} / \mathrm{L}$, milligram per liter; $\mu \mathrm{S} / \mathrm{cm}$, microsiemens per centimeter at 25 degrees Celsius; ORP, oxidation-reduction potential; mV, millivolt. Symbols: E, estimated value; R, data rejected (selected 1996 dissolved-oxygen data were rejected because of inadequate well purging; selected 2002 dissolved-hydrogen data were rejected because of interference from downhole instruments, 2011, dissolved-hydrogen data were rejected pending further investigation between U.S. Geological Survey field analysis and analyzing laboratory); <, actual value is less than value shown; >, actual value is greater than value shown; -, not analyzed]

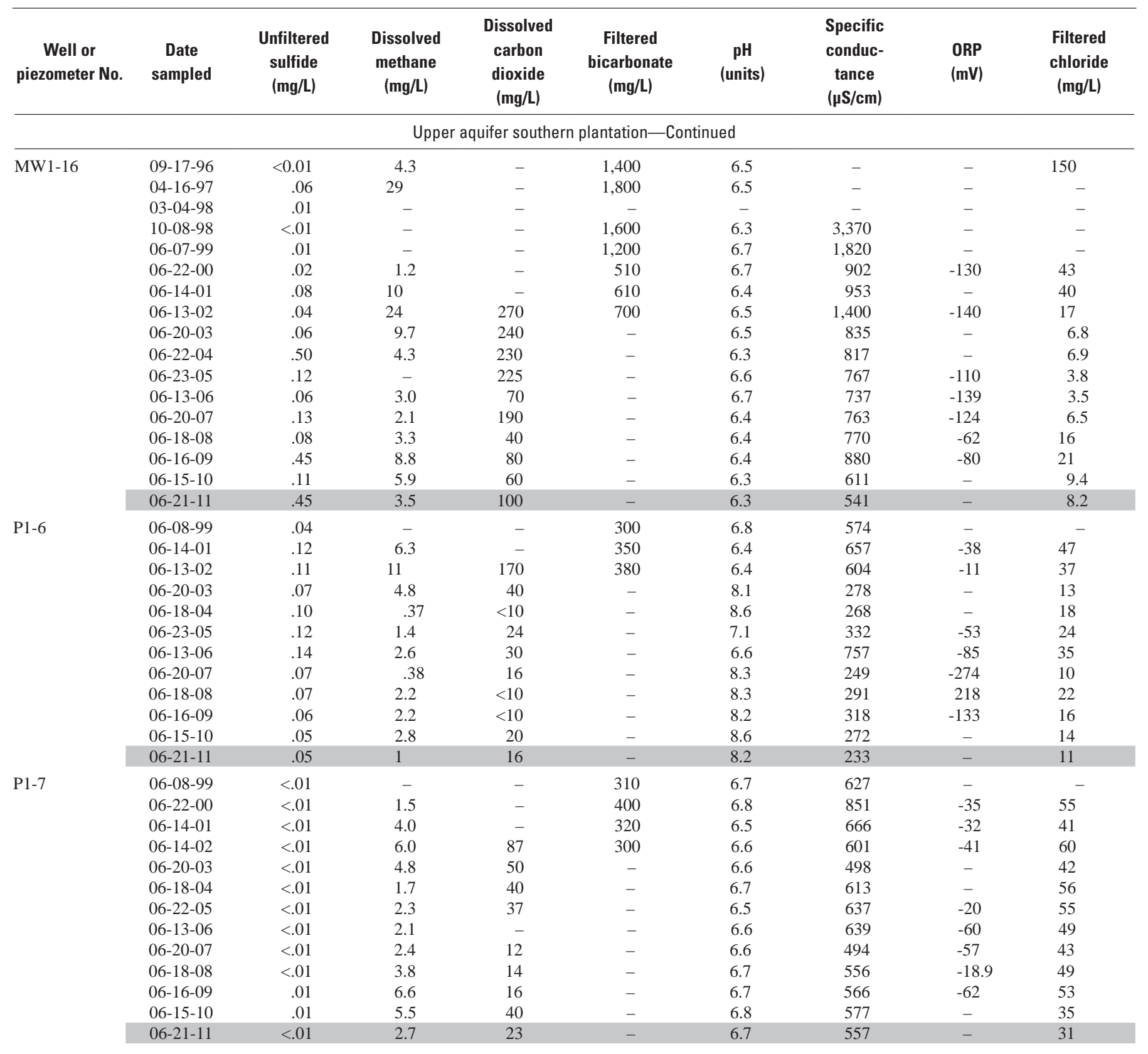


Table 2. Groundwater geochemical data collected at Operable Unit 1, Naval Undersea Warfare Center, Division Keyport, Washington, 1996-2011.-Continued

[All other data were published in Dinicola and others (2002), Dinicola (2003, 2004, 2006), Dinicola and Huffman (2004, 2006, 2007, 2009), and Dinicola and Huffman (2011); prior to 2000, bicarbonate was calculated from an unfiltered sample. Reported concentrations less than the detection limit usually are estimated. A range of dissolved hydrogen concentrations is shown when equilibration at a single value was never achieved. Well or piezometer No.: MW, monitoring well; P, piezometer. Abbreviations: $\mathrm{nM}$, nanomolar; $\mathrm{mg} / \mathrm{L}$, milligram per liter; $\mu \mathrm{S} / \mathrm{cm}$, microsiemens per centimeter at 25 degrees Celsius; ORP, oxidation-reduction potential; mV, millivolt. Symbols: E, estimated value; R, data rejected (selected 1996 dissolved-oxygen data were rejected because of inadequate well purging; selected 2002 dissolved-hydrogen data were rejected because of interference from downhole instruments, 2011, dissolved-hydrogen data were rejected pending further investigation between U.S. Geological Survey field analysis and analyzing laboratory); <, actual value is less than value shown; >, actual value is greater than value shown; -, not analyzed]

\begin{tabular}{|c|c|c|c|c|c|c|c|c|c|}
\hline $\begin{array}{c}\text { Well or } \\
\text { piezometer } \\
\text { No. }\end{array}$ & $\begin{array}{c}\text { Date } \\
\text { sampled }\end{array}$ & $\begin{array}{l}\text { Dissolved } \\
\text { hydrogen } \\
\text { (nM) }\end{array}$ & $\begin{array}{l}\text { Dissolved } \\
\text { oxygen } \\
\text { (mg/L) }\end{array}$ & $\begin{array}{c}\text { Unfiltered } \\
\text { (total) } \\
\text { organic carbon } \\
\text { (mg/L) }\end{array}$ & 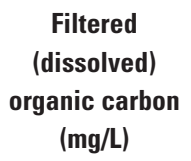 & $\begin{array}{c}\text { Filtered } \\
\text { nitrate + nitrite } \\
(\mathrm{mg} / \mathrm{L} \text { as } \mathrm{N})\end{array}$ & $\begin{array}{c}\text { Filtered } \\
\text { manganese } \\
(\mathrm{mg} / \mathrm{L})\end{array}$ & $\begin{array}{c}\text { Filtered } \\
\text { iron (II) } \\
\text { (mg/L) }\end{array}$ & $\begin{array}{c}\text { Filtered } \\
\text { sulfate } \\
\text { (mg/L) }\end{array}$ \\
\hline \multicolumn{10}{|c|}{ Upper aquifer southern plantation-Continued } \\
\hline \multirow[t]{8}{*}{ P1-8 } & 06-07-99 & 1.8 & $<0.1$ & - & - & - & 0.20 & 0.08 & - \\
\hline & 06-14-01 & .7 & .1 & 5 & 4.7 & 0.06 & .16 & .22 & 0.1 \\
\hline & 06-18-04 & .3 & .4 & - & 3.0 & - & .13 & .01 & .4 \\
\hline & 06-23-05 & .2 & .2 & - & 14 & $<.06$ & .12 & .12 & $<.2$ \\
\hline & 06-13-06 & .3 & $<.1$ & - & 3.2 & $<.06$ & .14 & .02 & .4 \\
\hline & 06-20-07 & .3 & .1 & - & 3.9 & $<.06$ & .15 & .14 & $<.18$ \\
\hline & 06-18-08 & .1 & $<.1$ & - & 4.1 & $<.04$ & .15 & .16 & .38 \\
\hline & 06-15-09 & .2 & $<.1$ & - & 3.5 & $<.04$ & .17 & .02 & .34 \\
\hline \multirow{11}{*}{ P1-9 } & 06-14-01 & 6.7 & .1 & 2.3 & 1.7 & $<.05$ & .19 & .05 & 7.6 \\
\hline & 06-13-02 & - & .6 & - & 9.8 & $<.05$ & 1.2 & .42 & 5.6 \\
\hline & 06-20-03 & .2 & .1 & - & 3.7 & $<.06$ & .24 & $<.01$ & 7.0 \\
\hline & 06-18-04 & .2 & .1 & - & 4.0 & - & .26 & .14 & 7.3 \\
\hline & $06-23-05$ & $<.1$ & .1 & - & 1.4 & $<.06$ & .11 & .01 & 8.7 \\
\hline & 06-13-06 & 4.4 & .2 & - & 9.6 & $<.06$ & 1.4 & .33 & 5.3 \\
\hline & 06-20-07 & .2 & .1 & - & 4.5 & $<.06$ & .28 & .13 & 7.04 \\
\hline & 06-18-08 & E.2.5 & $<.1$ & - & 10 & $<.04$ & .17 & .07 & 7.89 \\
\hline & 06-16-09 & $<.1$ & .2 & - & 6.0 & $<.04$ & .60 & .15 & 5.4 \\
\hline & $06-14-10$ & .2 & $<.1$ & - & 1.2 & $<.04$ & .16 & $<.01$ & 8.6 \\
\hline & 06-21-11 & $1 \mathrm{R}$ & .2 & - & 2.0 & $<.02$ & .20 & .04 & 7.2 \\
\hline \multirow[t]{4}{*}{ P1-10 } & 06-07-99 & .7 & .3 & - & - & - & .10 & .11 & - \\
\hline & $06-22-00$ & - & $<.1$ & 7.2 & - & - & .07 & .25 & $<0.3$ \\
\hline & 06-14-10 & .2 & .1 & - & 5 & $<.04$ & .28 & .19 & $<.2$ \\
\hline & 06-21-11 & $2.2 \mathrm{R}$ & .1 & - & 5.5 & $<.02$ & .43 & .25 & $<.09$ \\
\hline
\end{tabular}


Table 2. Groundwater geochemical data collected at Operable Unit 1, Naval Undersea Warfare Center, Division Keyport, Washington, 1996-2011.-Continued

[All other data were published in Dinicola and others (2002), Dinicola (2003, 2004, 2006), Dinicola and Huffman (2004, 2006, 2007, 2009), and Dinicola and Huffman (2011); prior to 2000, bicarbonate was calculated from an unfiltered sample. Reported concentrations less than the detection limit usually are estimated. A range of dissolved hydrogen concentrations is shown when equilibration at a single value was never achieved. Well or piezometer No.: MW, monitoring well; P, piezometer. Abbreviations: nM, nanomolar; $\mathrm{mg} / \mathrm{L}$, milligram per liter; $\mu \mathrm{S} / \mathrm{cm}$, microsiemens per centimeter at 25 degrees Celsius; ORP, oxidation-reduction potential; mV, millivolt. Symbols: E, estimated value; R, data rejected (selected 1996 dissolved-oxygen data were rejected because of inadequate well purging; selected 2002 dissolved-hydrogen data were rejected because of interference from downhole instruments, 2011, dissolved-hydrogen data were rejected pending further investigation between U.S. Geological Survey field analysis and analyzing laboratory); <, actual value is less than value shown; >, actual value is greater than value shown; -, not analyzed]

\begin{tabular}{|c|c|c|c|c|c|c|c|c|c|}
\hline $\begin{array}{c}\text { Well or } \\
\text { piezometer No. }\end{array}$ & $\begin{array}{c}\text { Date } \\
\text { sampled }\end{array}$ & $\begin{array}{l}\text { Unfiltered } \\
\text { sulfide } \\
\text { (mg/L) }\end{array}$ & $\begin{array}{c}\text { Dissolved } \\
\text { methane } \\
\text { (mg/L) }\end{array}$ & $\begin{array}{c}\text { Dissolved } \\
\text { carbon } \\
\text { dioxide } \\
\text { (mg/L) }\end{array}$ & $\begin{array}{c}\text { Filtered } \\
\text { bicarbonate } \\
(\mathrm{mg} / \mathrm{L})\end{array}$ & $\begin{array}{c}\mathrm{pH} \\
\text { (units) }\end{array}$ & $\begin{array}{c}\text { Specific } \\
\text { conduc- } \\
\text { tance } \\
(\mu \mathrm{S} / \mathrm{cm})\end{array}$ & $\begin{array}{l}\text { ORP } \\
(\mathrm{mV})\end{array}$ & $\begin{array}{c}\text { Filtered } \\
\text { chloride } \\
(\mathrm{mg} / \mathrm{L})\end{array}$ \\
\hline \multicolumn{10}{|c|}{ Upper aquifer southern plantation-Continued } \\
\hline \multirow[t]{8}{*}{ P1-8 } & 06-07-99 & 0.01 & - & - & 210 & 7.6 & 381 & - & - \\
\hline & 06-14-01 & .02 & 6.9 & - & 200 & 7.0 & 363 & -73 & 18 \\
\hline & 06-18-04 & .01 & 1.7 & $<10$ & - & 7.4 & 336 & -218 & 5.9 \\
\hline & 06-23-05 & $<.01$ & 3.4 & $<10$ & - & 7.5 & 308 & -147 & 4.2 \\
\hline & 06-13-06 & $<.01$ & 4.5 & $<10$ & - & 7.5 & 332 & -124 & 8.0 \\
\hline & 06-20-07 & $<.01$ & 6.6 & 9 & - & 7.5 & 348 & -149 & 5.9 \\
\hline & 06-18-08 & $<.01$ & 7.9 & $<10$ & - & 8.0 & 358 & -136 & 8.7 \\
\hline & 06-15-08 & $<.01$ & 10 & $<10$ & - & 7.9 & 356 & -164 & 6.7 \\
\hline \multirow{11}{*}{ P1-9 } & 06-14-01 & $<.01$ & 1.4 & - & 200 & 7.8 & 289 & -120 & 14 \\
\hline & 06-13-02 & $<.01$ & 7.5 & 91 & 280 & 6.5 & 601 & 17 & 71 \\
\hline & 06-20-03 & .01 & 2.5 & 27 & - & 7.0 & 353 & - & 23 \\
\hline & 06-18-04 & $<.01$ & .71 & 35 & - & 6.7 & 330 & -97 & 26 \\
\hline & 06-23-05 & $<.01$ & .02 & $<10$ & - & 8.3 & 202 & 22 & 12 \\
\hline & 06-13-06 & .01 & 3.2 & 37 & - & 6.6 & 728 & -9 & 112 \\
\hline & 06-20-07 & $<.01$ & 1.4 & 10 & - & 7.4 & 325 & -110 & 31 \\
\hline & 06-18-08 & $<.01$ & .74 & $<10$ & - & 7.6 & 235 & - & 28 \\
\hline & 06-16-09 & $<.01$ & 6.7 & 14 & - & 6.8 & 507 & -27 & 72 \\
\hline & 06-14-10 & $<.01$ & .6 & 12 & - & 8.3 & 233 & - & 19 \\
\hline & 06-21-11 & $<.01$ & 1.2 & $<10$ & - & 7.5 & 326 & - & 28 \\
\hline \multirow[t]{5}{*}{$\mathrm{P} 1-10$} & 06-07-99 & $<.01$ & - & - & 300 & 6.7 & 560 & - & - \\
\hline & $06-22-00$ & $<.01$ & 1.3 & - & 290 & 7.1 & 500 & -19 & 15 \\
\hline & 06-15-09 & $<.01$ & 3.4 & 35 & - & 6.7 & 406 & -6.1 & 6.6 \\
\hline & 06-14-10 & $<.01$ & 4.1 & 50 & - & 6.7 & 431 & - & 6.5 \\
\hline & 06-21-11 & $<.01$ & 3.6 & 40 & - & 6.8 & 407 & - & 5.6 \\
\hline
\end{tabular}


Table 2. Groundwater geochemical data collected at Operable Unit 1, Naval Undersea Warfare Center, Division Keyport, Washington, 1996-2011.-Continued

[All other data were published in Dinicola and others (2002), Dinicola (2003, 2004, 2006), Dinicola and Huffman (2004, 2006, 2007, 2009), and Dinicola and Huffman (2011); prior to 2000, bicarbonate was calculated from an unfiltered sample. Reported concentrations less than the detection limit usually are estimated. A range of dissolved hydrogen concentrations is shown when equilibration at a single value was never achieved. Well or piezometer No.: MW, monitoring well; P, piezometer. Abbreviations: nM, nanomolar; mg/L, milligram per liter; $\mu \mathrm{S} / \mathrm{cm}$, microsiemens per centimeter at 25 degrees Celsius; ORP, oxidation-reduction potential; mV, millivolt. Symbols: E, estimated value; R, data rejected (selected 1996 dissolved-oxygen data were rejected because of inadequate well purging; selected 2002 dissolved-hydrogen data were rejected because of interference from downhole instruments, 2011, dissolved-hydrogen data were rejected pending further investigation between U.S. Geological Survey field analysis and analyzing laboratory); <, actual value is less than value shown; >, actual value is greater than value shown; -, not analyzed]

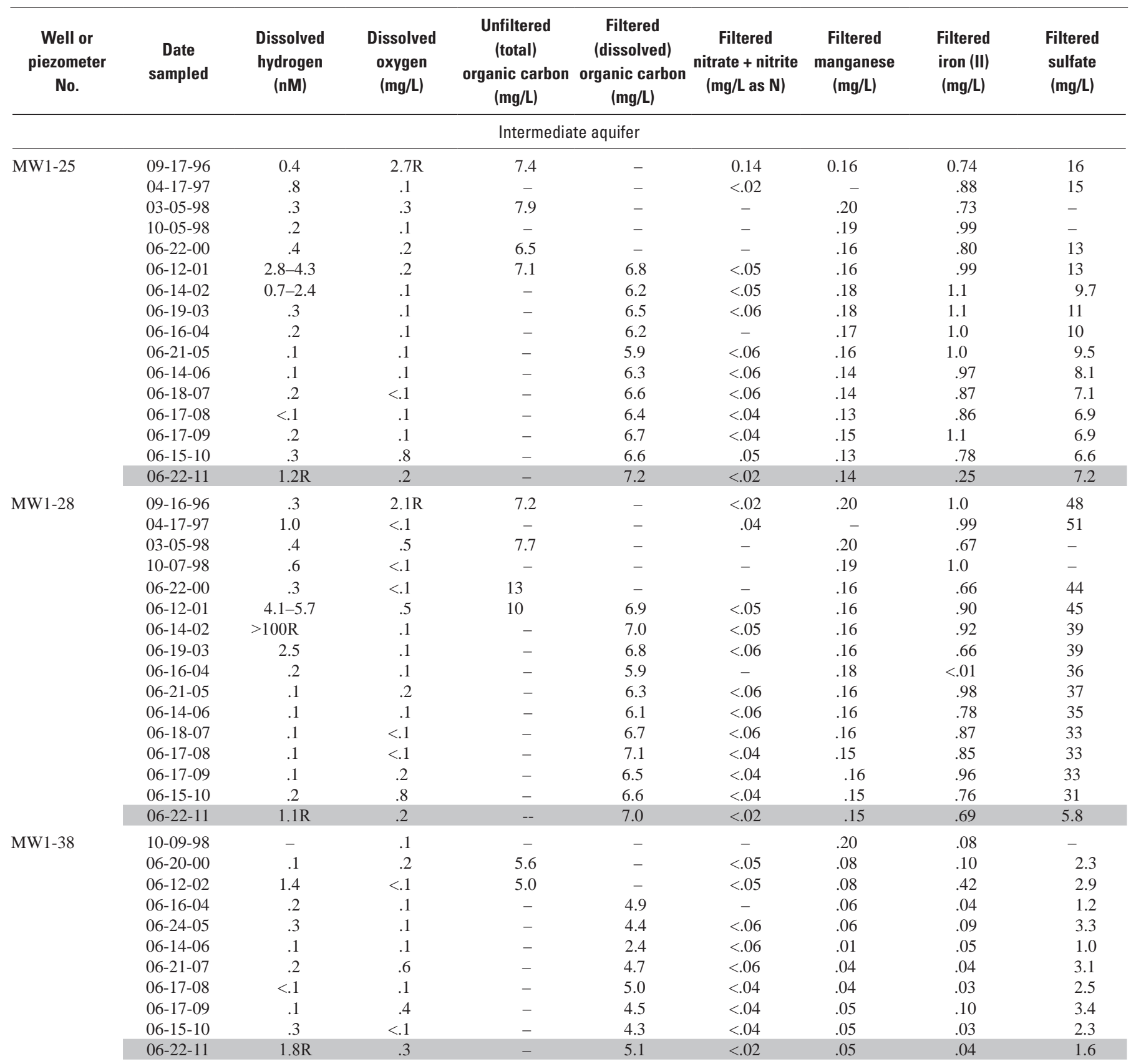


Table 2. Groundwater geochemical data collected at Operable Unit 1, Naval Undersea Warfare Center, Division Keyport, Washington, 1996-2011.-Continued

[All other data were published in Dinicola and others (2002), Dinicola (2003, 2004, 2006), Dinicola and Huffman (2004, 2006, 2007, 2009), and Dinicola and Huffman (2011); prior to 2000, bicarbonate was calculated from an unfiltered sample. Reported concentrations less than the detection limit usually are estimated. A range of dissolved hydrogen concentrations is shown when equilibration at a single value was never achieved. Well or piezometer No.: MW, monitoring well; P, piezometer. Abbreviations: nM, nanomolar; $\mathrm{mg} / \mathrm{L}$, milligram per liter; $\mu \mathrm{S} / \mathrm{cm}$, microsiemens per centimeter at 25 degrees Celsius; ORP, oxidation-reduction potential; mV, millivolt. Symbols: E, estimated value; R, data rejected (selected 1996 dissolved-oxygen data were rejected because of inadequate well purging; selected 2002 dissolved-hydrogen data were rejected because of interference from downhole instruments, 2011, dissolved-hydrogen data were rejected pending further investigation between U.S. Geological Survey field analysis and analyzing laboratory); <, actual value is less than value shown; >, actual value is greater than value shown; -, not analyzed]

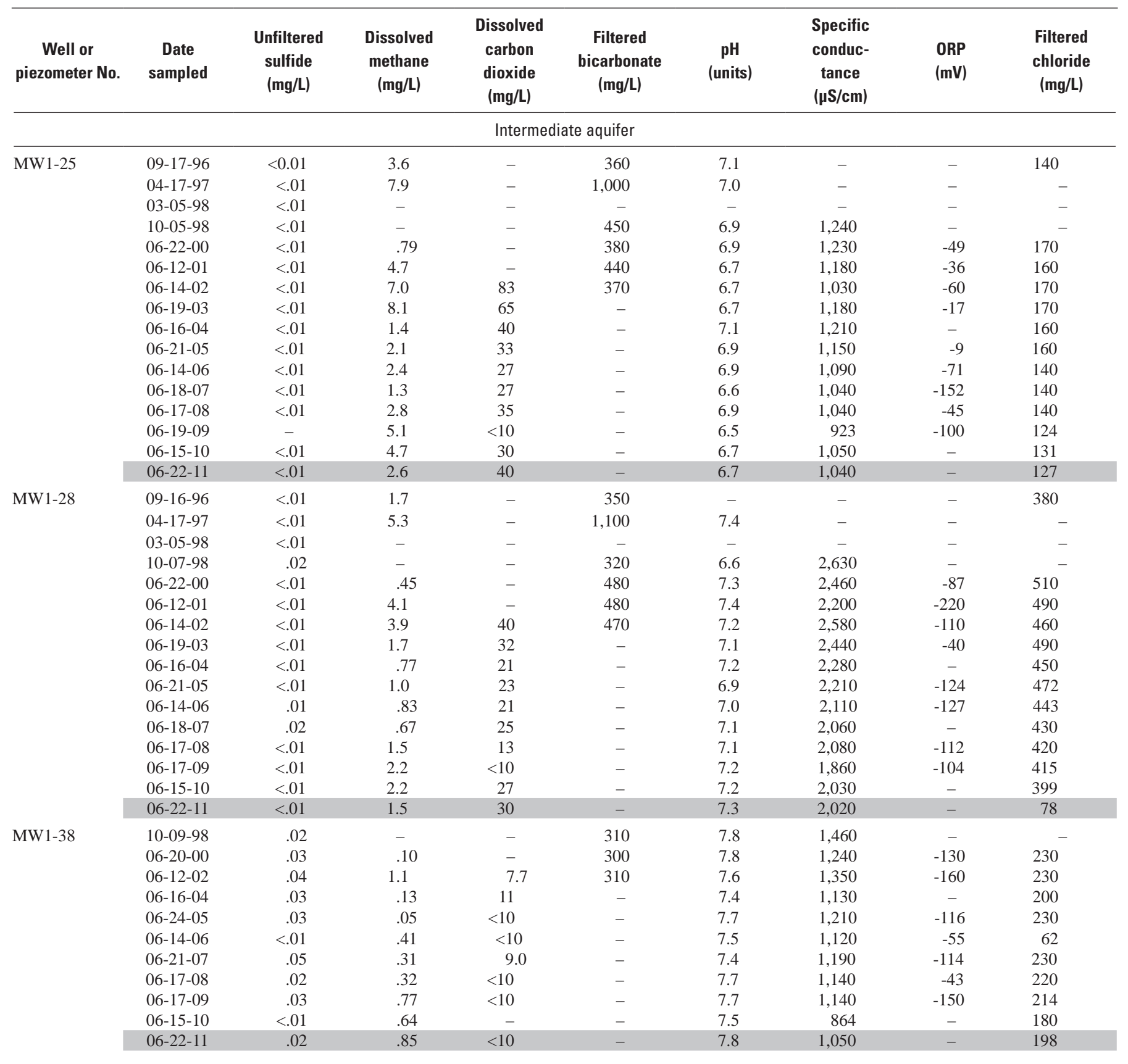


Table 2. Groundwater geochemical data collected at Operable Unit 1, Naval Undersea Warfare Center, Division Keyport, Washington, 1996-2011.-Continued

[All other data were published in Dinicola and others (2002), Dinicola (2003, 2004, 2006), Dinicola and Huffman (2004, 2006, 2007, 2009), and Dinicola and Huffman (2011); prior to 2000, bicarbonate was calculated from an unfiltered sample. Reported concentrations less than the detection limit usually are estimated. A range of dissolved hydrogen concentrations is shown when equilibration at a single value was never achieved. Well or piezometer No.: MW, monitoring well; P, piezometer. Abbreviations: nM, nanomolar; $\mathrm{mg} / \mathrm{L}$, milligram per liter; $\mu \mathrm{S} / \mathrm{cm}$, microsiemens per centimeter at 25 degrees Celsius; ORP, oxidation-reduction potential; mV, millivolt. Symbols: E, estimated value; R, data rejected (selected 1996 dissolved-oxygen data were rejected because of inadequate well purging; selected 2002 dissolved-hydrogen data were rejected because of interference from downhole instruments, 2011, dissolved-hydrogen data were rejected pending further investigation between U.S. Geological Survey field analysis and analyzing laboratory); <, actual value is less than value shown; >, actual value is greater than value shown; -, not analyzed]

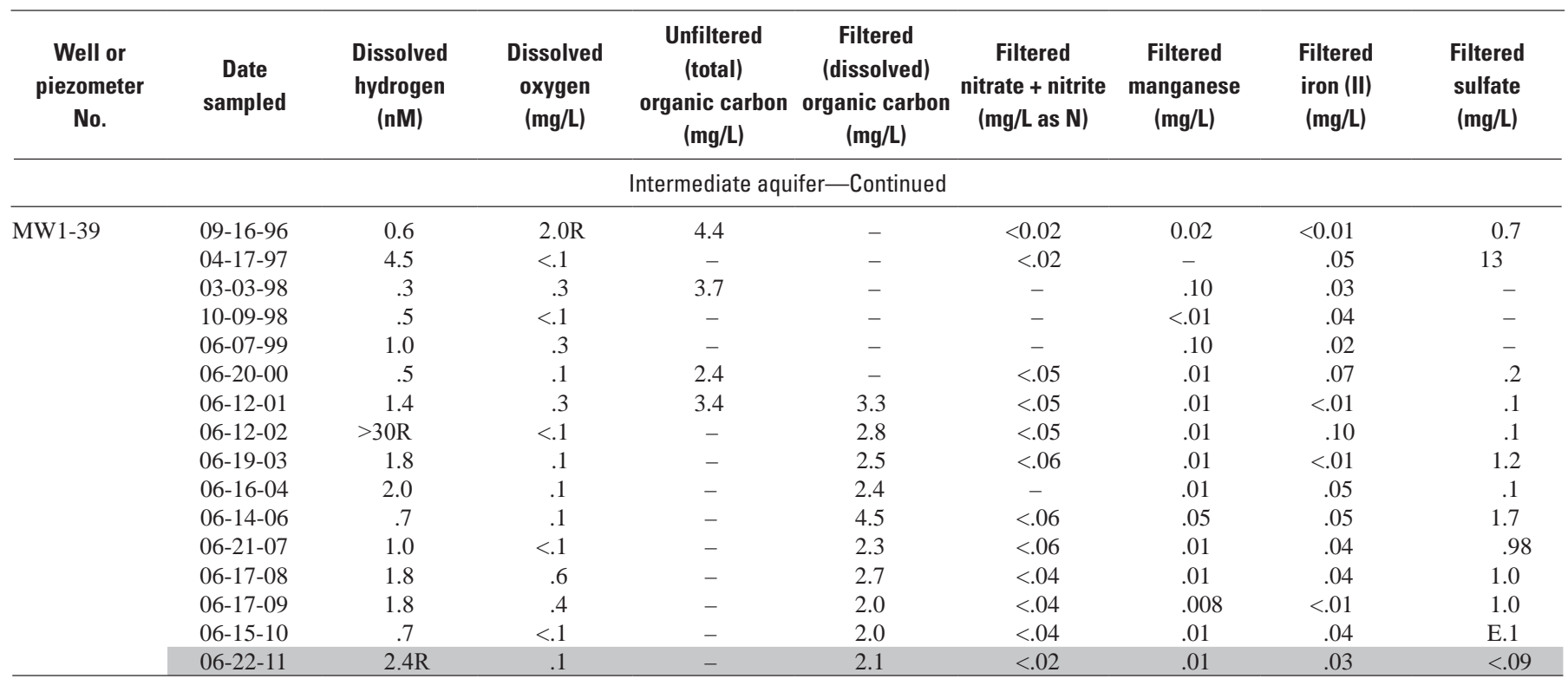


Table 3. Concentrations of selected volatile organic compounds in groundwater samples from monitoring wells and piezometers collected by the U.S. Geological Survey at Operable Unit 1, Naval Undersea Warfare Center, Division Keyport, Washington, 1999-2011.

[All data except those shaded were published previously in Dinicola and others (2002), Dinicola (2003, 2004, 2006), Dinicola and Huffman (2004, 2006, 2007, 2009), and Dinicola and Huffman (2011). Laboratory data qualifier codes, such as "D" for dilution, are not shown. Volatile organic compounds (VOCs): PCE, tetrachloroethene; TCE, trichloroethene; cis-DCE, cis-1,2-dichloroethene; trans-DCE, trans-1,2-dichloroethene; VC, vinyl chloride; 1,1,1-TCA, 1,1,1-trichloroethane; 1,1-DCA, 1,1-dichloroethane; CA, chloroethane; 1,1-DCE, 1,1-dichloroethene; total BTEX, sum of benzene, toluene, ethylbenzene, and xylene; total CVOCs, sum of chlorinated volatile organic compounds. Abbreviations: E, estimated value; M, presence verified but not quantified; $\mu \mathrm{g} / \mathrm{L}$, microgram per liter; <, actual value is less than value shown; ND, not detected; -, not analyzed]

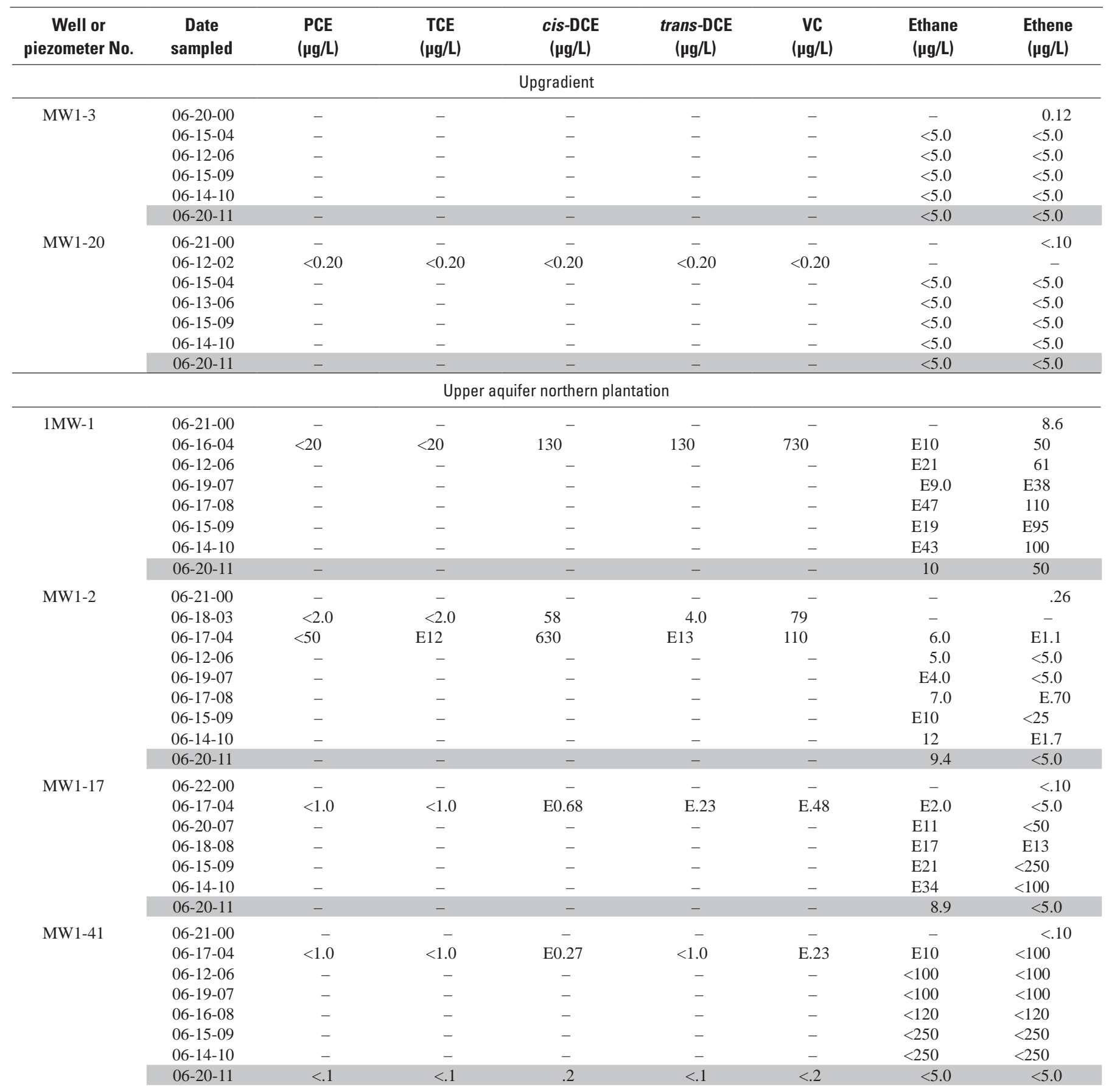


Table 3. Concentrations of selected volatile organic compounds in groundwater samples from monitoring wells and piezometers collected by the U.S. Geological Survey at Operable Unit 1, Naval Undersea Warfare Center, Division Keyport, Washington, $1999-2011$. - Continued

[All data except those shaded were published previously in Dinicola and others (2002), Dinicola (2003, 2004, 2006), Dinicola and Huffman (2004, 2006, 2007, 2009), and Dinicola and Huffman (2011). Laboratory data qualifier codes, such as "D" for dilution, are not shown. Volatile organic compounds (VOCs): PCE, tetrachloroethene; TCE, trichloroethene; cis-DCE, cis-1,2-dichloroethene; trans-DCE, trans-1,2-dichloroethene; VC, vinyl chloride; 1,1,1-TCA, 1,1,1-trichloroethane; 1,1-DCA, 1,1-dichloroethane; CA, chloroethane; 1,1-DCE, 1,1-dichloroethene; total BTEX, sum of benzene, toluene, ethylbenzene, and xylene; total CVOCs, sum of chlorinated volatile organic compounds. Abbreviations: E, estimated value; M, presence verified but not quantified; $\mu \mathrm{g} / \mathrm{L}$, microgram per liter; <, actual value is less than value shown; ND, not detected; -, not analyzed]

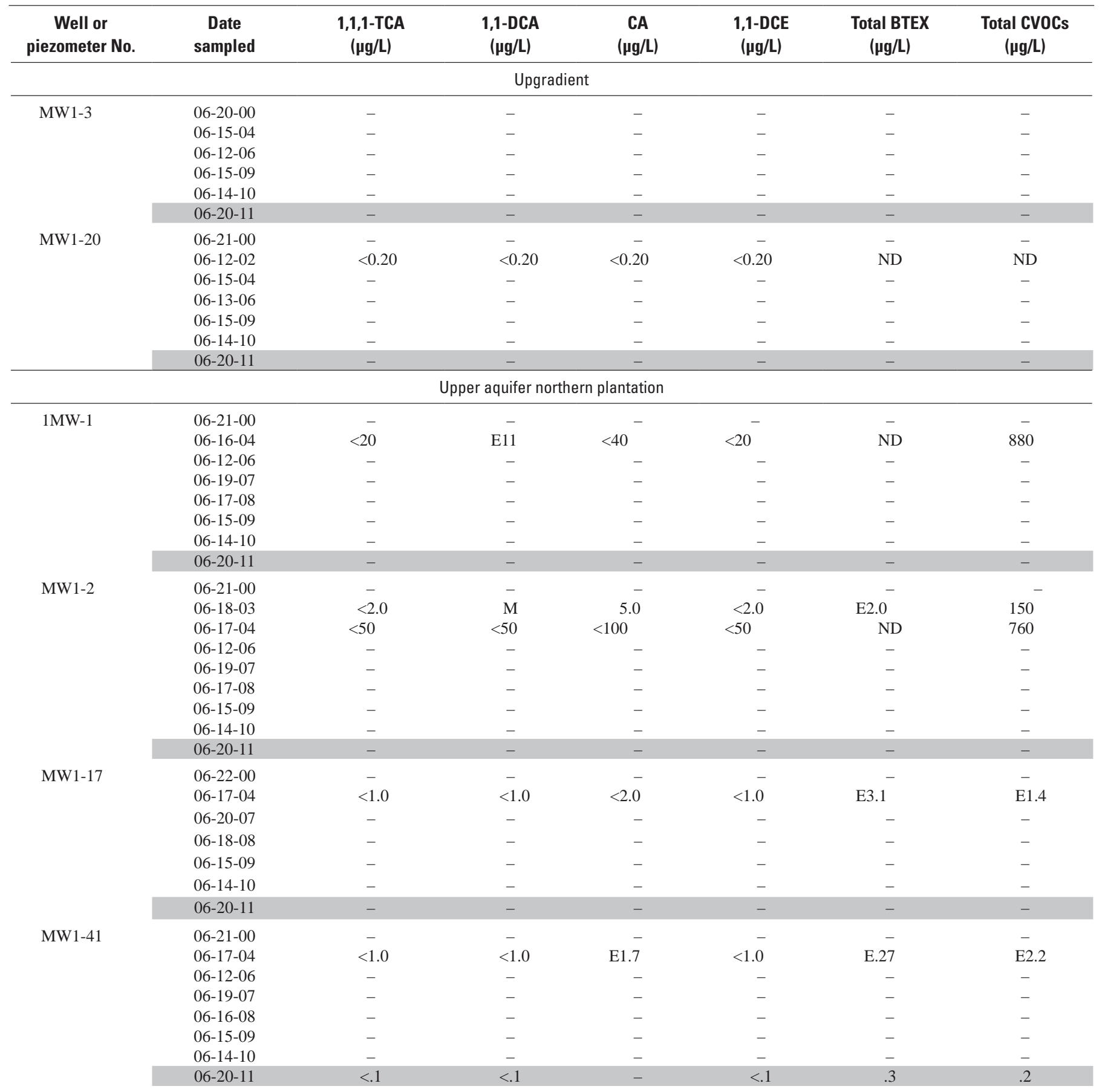


Table 3. Concentrations of selected volatile organic compounds in groundwater samples from monitoring wells and piezometers collected by the U.S. Geological Survey at Operable Unit 1, Naval Undersea Warfare Center, Division Keyport, Washington, 1999-2011. -Continued

[All data except those shaded were published previously in Dinicola and others (2002), Dinicola (2003, 2004, 2006), Dinicola and Huffman (2004, 2006, 2007, 2009), and Dinicola and Huffman (2011). Laboratory data qualifier codes, such as "D" for dilution, are not shown. Volatile organic compounds (VOCs): PCE, tetrachloroethene; TCE, trichloroethene; cis-DCE, cis-1,2-dichloroethene; trans-DCE, trans-1,2-dichloroethene; VC, vinyl chloride; 1,1,1-TCA, 1,1,1-trichloroethane; 1,1-DCA, 1,1-dichloroethane; CA, chloroethane; 1,1-DCE, 1,1-dichloroethene; total BTEX, sum of benzene, toluene, ethylbenzene, and xylene; total CVOCs, sum of chlorinated volatile organic compounds. Abbreviations: E, estimated value; M, presence verified but not quantified; $\mu \mathrm{g} / \mathrm{L}$, microgram per liter; <, actual value is less than value shown; ND, not detected; -, not analyzed]

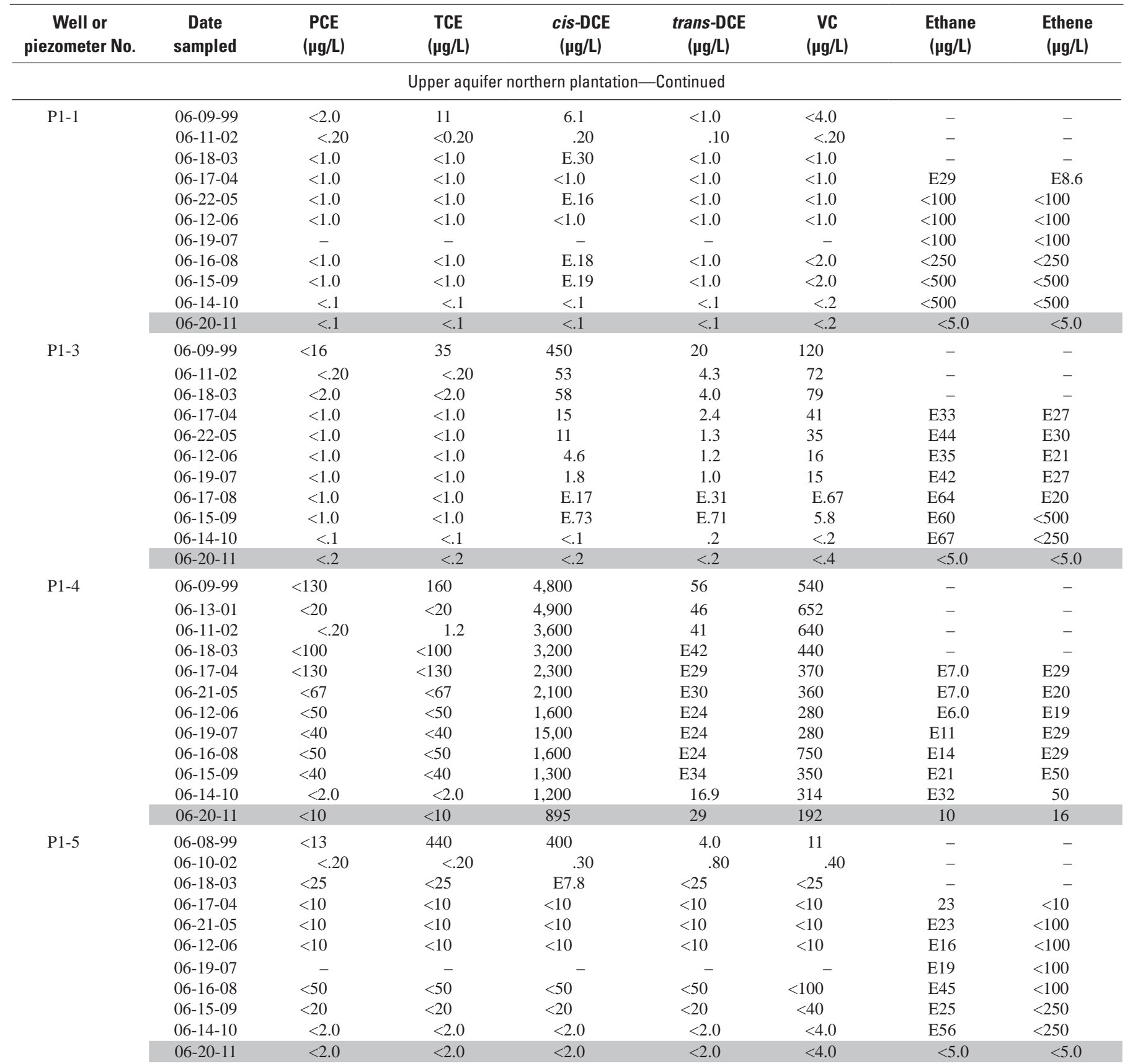


Table 3. Concentrations of selected volatile organic compounds in groundwater samples from monitoring wells and piezometers collected by the U.S. Geological Survey at Operable Unit 1, Naval Undersea Warfare Center, Division Keyport, Washington, $1999-2011$.

\section{-Continued}

[All data except those shaded were published previously in Dinicola and others (2002), Dinicola (2003, 2004, 2006), Dinicola and Huffman (2004, 2006, 2007, 2009), and Dinicola and Huffman (2011). Laboratory data qualifier codes, such as "D" for dilution, are not shown. Volatile organic compounds (VOCs): PCE, tetrachloroethene; TCE, trichloroethene; cis-DCE, cis-1,2-dichloroethene; trans-DCE, trans-1,2-dichloroethene; VC, vinyl chloride; 1,1,1-TCA, 1,1,1-trichloroethane; 1,1-DCA, 1,1-dichloroethane; CA, chloroethane; 1,1-DCE, 1,1-dichloroethene; total BTEX, sum of benzene, toluene, ethylbenzene, and xylene; total CVOCs, sum of chlorinated volatile organic compounds. Abbreviations: E, estimated value; M, presence verified but not quantified; $\mu \mathrm{g} / \mathrm{L}$, microgram per liter; <, actual value is less than value shown; ND, not detected; -, not analyzed]

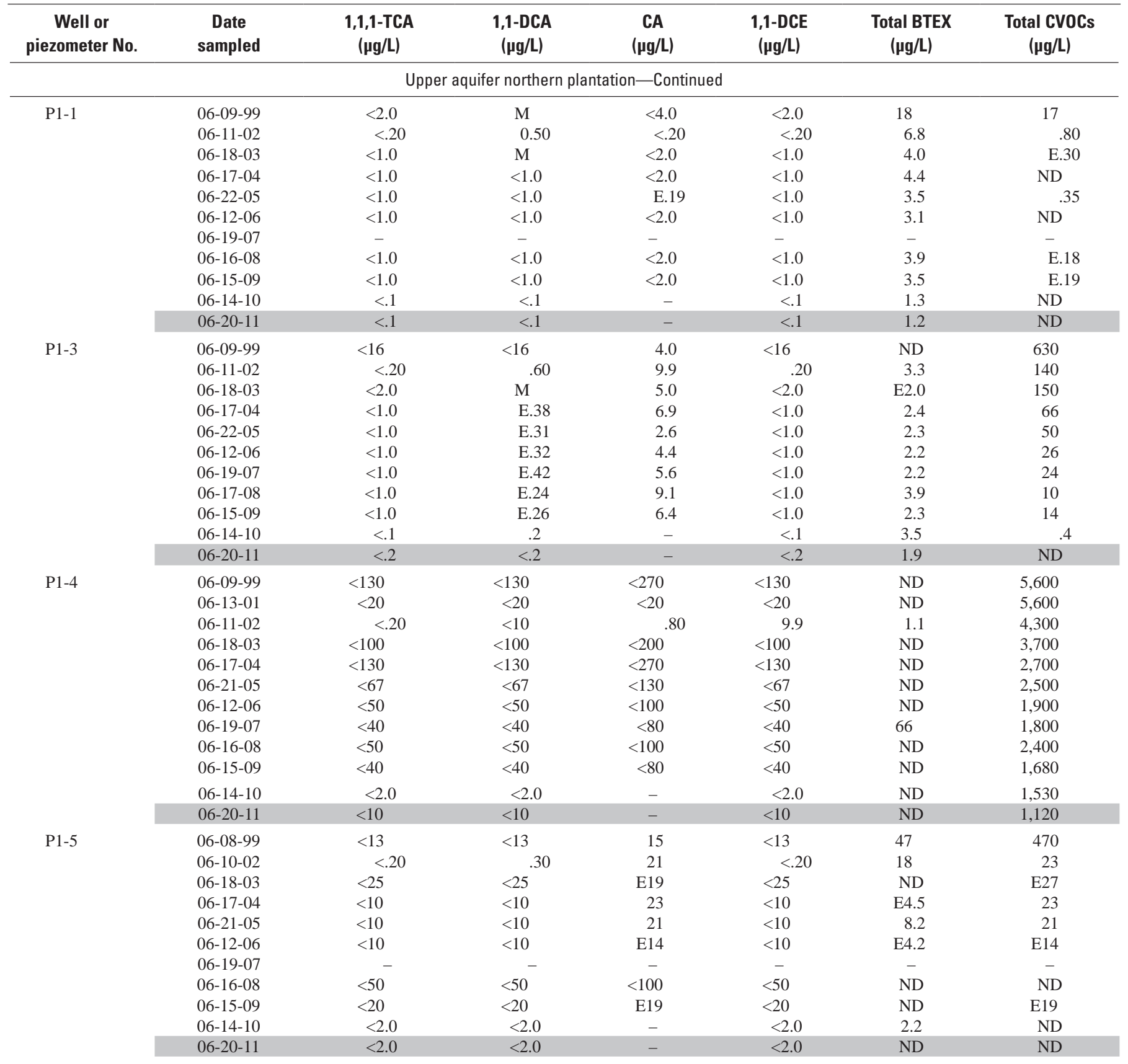


Table 3. Concentrations of selected volatile organic compounds in groundwater samples from monitoring wells and piezometers collected by the U.S. Geological Survey at Operable Unit 1, Naval Undersea Warfare Center, Division Keyport, Washington, 1999-2011. -Continued

[All data except those shaded were published previously in Dinicola and others (2002), Dinicola (2003, 2004, 2006), Dinicola and Huffman (2004, 2006, 2007, 2009), and Dinicola and Huffman (2011). Laboratory data qualifier codes, such as "D" for dilution, are not shown. Volatile organic compounds (VOCs): PCE, tetrachloroethene; TCE, trichloroethene; cis-DCE, cis-1,2-dichloroethene; trans-DCE, trans-1,2-dichloroethene; VC, vinyl chloride; 1,1,1-TCA, 1,1,1-trichloroethane; 1,1-DCA, 1,1-dichloroethane; CA, chloroethane; 1,1-DCE, 1,1-dichloroethene; total BTEX, sum of benzene, toluene, ethylbenzene, and xylene; total CVOCs, sum of chlorinated volatile organic compounds. Abbreviations: E, estimated value; M, presence verified but not quantified; $\mu \mathrm{g} / \mathrm{L}$, microgram per liter; <, actual value is less than value shown; ND, not detected; -, not analyzed]

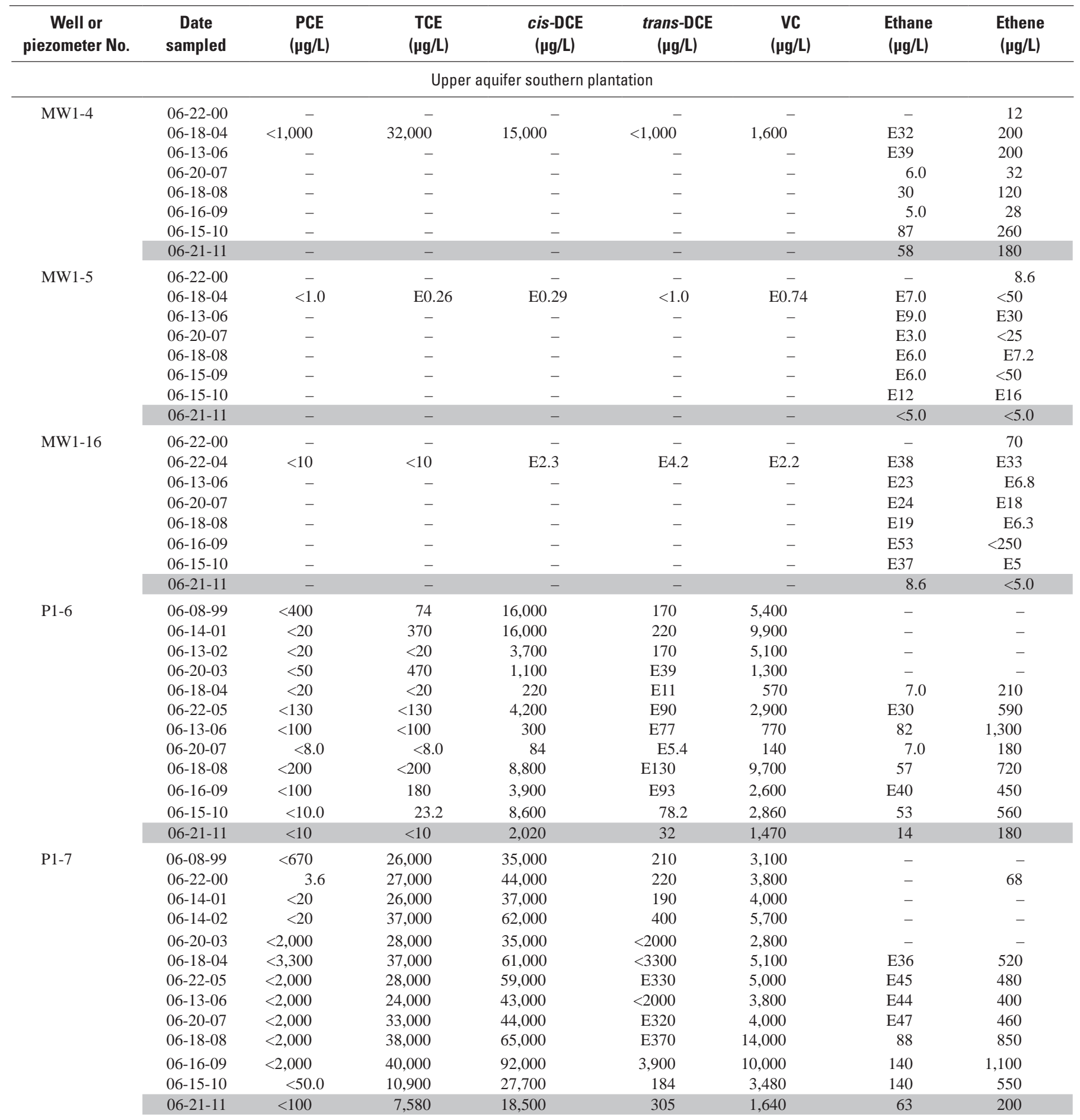


Table 3. Concentrations of selected volatile organic compounds in groundwater samples from monitoring wells and piezometers collected by the U.S. Geological Survey at Operable Unit 1, Naval Undersea Warfare Center, Division Keyport, Washington, $1999-2011$. -Continued

[All data except those shaded were published previously in Dinicola and others (2002), Dinicola (2003, 2004, 2006), Dinicola and Huffman (2004, 2006, 2007, 2009), and Dinicola and Huffman (2011). Laboratory data qualifier codes, such as "D" for dilution, are not shown. Volatile organic compounds

(VOCs): PCE, tetrachloroethene; TCE, trichloroethene; cis-DCE, cis-1,2-dichloroethene; trans-DCE, trans-1,2-dichloroethene; VC, vinyl chloride; 1,1,1-TCA, 1,1,1-trichloroethane; 1,1-DCA, 1,1-dichloroethane; CA, chloroethane; 1,1-DCE, 1,1-dichloroethene; total BTEX, sum of benzene, toluene, ethylbenzene, and xylene; total CVOCs, sum of chlorinated volatile organic compounds. Abbreviations: E, estimated value; M, presence verified but not quantified; $\mu \mathrm{g} / \mathrm{L}$, microgram per liter; <, actual value is less than value shown; ND, not detected; -, not analyzed]

\begin{tabular}{|c|c|c|c|c|c|c|c|}
\hline $\begin{array}{c}\text { Well or } \\
\text { piezometer No. }\end{array}$ & $\begin{array}{c}\text { Date } \\
\text { sampled }\end{array}$ & $\begin{array}{c}1,1,1-\mathrm{TCA} \\
(\mu \mathrm{g} / \mathrm{L})\end{array}$ & $\begin{array}{c}\text { 1,1-DCA } \\
(\mu \mathrm{g} / \mathrm{L})\end{array}$ & $\begin{array}{c}\text { CA } \\
(\mu g / L)\end{array}$ & $\begin{array}{c}\text { 1,1-DCE } \\
(\mu \mathrm{g} / \mathrm{L})\end{array}$ & $\begin{array}{c}\text { Total BTEX } \\
(\mu \mathrm{g} / \mathrm{L})\end{array}$ & $\begin{array}{c}\text { Total CVOCs } \\
(\mu \mathrm{g} / \mathrm{L})\end{array}$ \\
\hline \multicolumn{8}{|c|}{ Upper aquifer southern plantation } \\
\hline \multirow{5}{*}{ MW1-4 } & 06-18-04 & $<1,000$ & $<1,000$ & $<2,000$ & $<1,000$ & ND & 49,000 \\
\hline & 06-13-06 & - & - & - & - & - & - \\
\hline & 06-20-07 & - & - & - & - & - & - \\
\hline & $06-15-10$ & - & - & - & - & - & - \\
\hline & 06-21-11 & - & - & - & - & - & -- \\
\hline \multirow[t]{4}{*}{ MW1-5 } & $06-22-00$ & - & - & - & - & - & - \\
\hline & 06-18-04 & $<1.0$ & E0.36 & 3.0 & $<1.0$ & E0.92 & E1.6 \\
\hline & 06-13-06 & - & - & - & - & - & - \\
\hline & $06-20-07$ & - & - & - & - & - & - \\
\hline \multirow{7}{*}{ MW1-16 } & $06-22-04$ & $<10$ & 590 & 290 & $<10$ & 367 & 890 \\
\hline & 06-13-06 & - & - & - & - & - & - \\
\hline & 06-20-07 & - & - & - & - & - & - \\
\hline & 06-18-08 & - & - & - & - & - & - \\
\hline & 06-16-09 & - & - & - & - & - & - \\
\hline & $06-15-10$ & - & - & - & - & - & - \\
\hline & 06-21-11 & - & - & - & - & - & - \\
\hline \multirow[t]{5}{*}{ P1-6 } & 06-08-99 & $<400$ & 1,500 & 300 & $<400$ & E87 & 23,000 \\
\hline & 06-14-01 & $<20$ & 4,800 & 600 & 12 & 88 & 32,000 \\
\hline & 06-13-02 & $<20$ & 4,300 & 1,400 & $<20$ & 63 & 15,000 \\
\hline & $06-20-03$ & $<50$ & 380 & 270 & $<50$ & ND & 3,600 \\
\hline & $06-18-04$ & $<20$ & 200 & 88 & $<20$ & ND & 1,100 \\
\hline \multirow{12}{*}{ P1-7 } & $06-22-00$ & .24 & 17 & 8.4 & 72 & - & 75,000 \\
\hline & 06-14-01 & $<20$ & $<20$ & $<20$ & 44 & ND & 67,000 \\
\hline & $06-14-02$ & $<20$ & 14 & $<20$ & 64 & ND & 105,000 \\
\hline & 06-20-03 & $<2,000$ & $<2,000$ & $<4,000$ & $<2,000$ & ND & 66,000 \\
\hline & 06-18-04 & $<3,300$ & $<3,300$ & $<6,700$ & $<3,300$ & ND & 103,000 \\
\hline & $06-22-05$ & $<2,000$ & $<2,000$ & $<4,000$ & $<2,000$ & ND & 92,000 \\
\hline & 06-13-06 & $<2,000$ & $<2,000$ & $<4,000$ & $<2,000$ & ND & 71,000 \\
\hline & 06-20-07 & $<2,000$ & $<2,000$ & $<4,000$ & $<2,000$ & ND & 81,000 \\
\hline & 06-18-08 & $<2,000$ & $<2,000$ & $<4,000$ & $<2,000$ & ND & 117,000 \\
\hline & 06-16-09 & $<2,000$ & $<2,000$ & $<4,000$ & $<2,000$ & ND & 146,000 \\
\hline & $06-15-10$ & $<50.0$ & $<50.0$ & - & $<50.0$ & ND & 43,000 \\
\hline & 06-21-11 & $<100$ & $<100$ & - & $<100$ & ND & 28,000 \\
\hline
\end{tabular}


Table 3. Concentrations of selected volatile organic compounds in groundwater samples from monitoring wells and piezometers collected by the U.S. Geological Survey at Operable Unit 1, Naval Undersea Warfare Center, Division Keyport, Washington, 1999-2011. -Continued

[All data except those shaded were published previously in Dinicola and others (2002), Dinicola (2003, 2004, 2006), Dinicola and Huffman (2004, 2006, 2007, 2009), and Dinicola and Huffman (2011). Laboratory data qualifier codes, such as "D" for dilution, are not shown. Volatile organic compounds (VOCs): PCE, tetrachloroethene; TCE, trichloroethene; cis-DCE, cis-1,2-dichloroethene; trans-DCE, trans-1,2-dichloroethene; VC, vinyl chloride; 1,1,1-TCA, 1,1,1-trichloroethane; 1,1-DCA, 1,1-dichloroethane; CA, chloroethane; 1,1-DCE, 1,1-dichloroethene; total BTEX, sum of benzene, toluene, ethylbenzene, and xylene; total CVOCs, sum of chlorinated volatile organic compounds. Abbreviations: E, estimated value; M, presence verified but not quantified; $\mu \mathrm{g} / \mathrm{L}$, microgram per liter; <, actual value is less than value shown; ND, not detected; -, not analyzed]

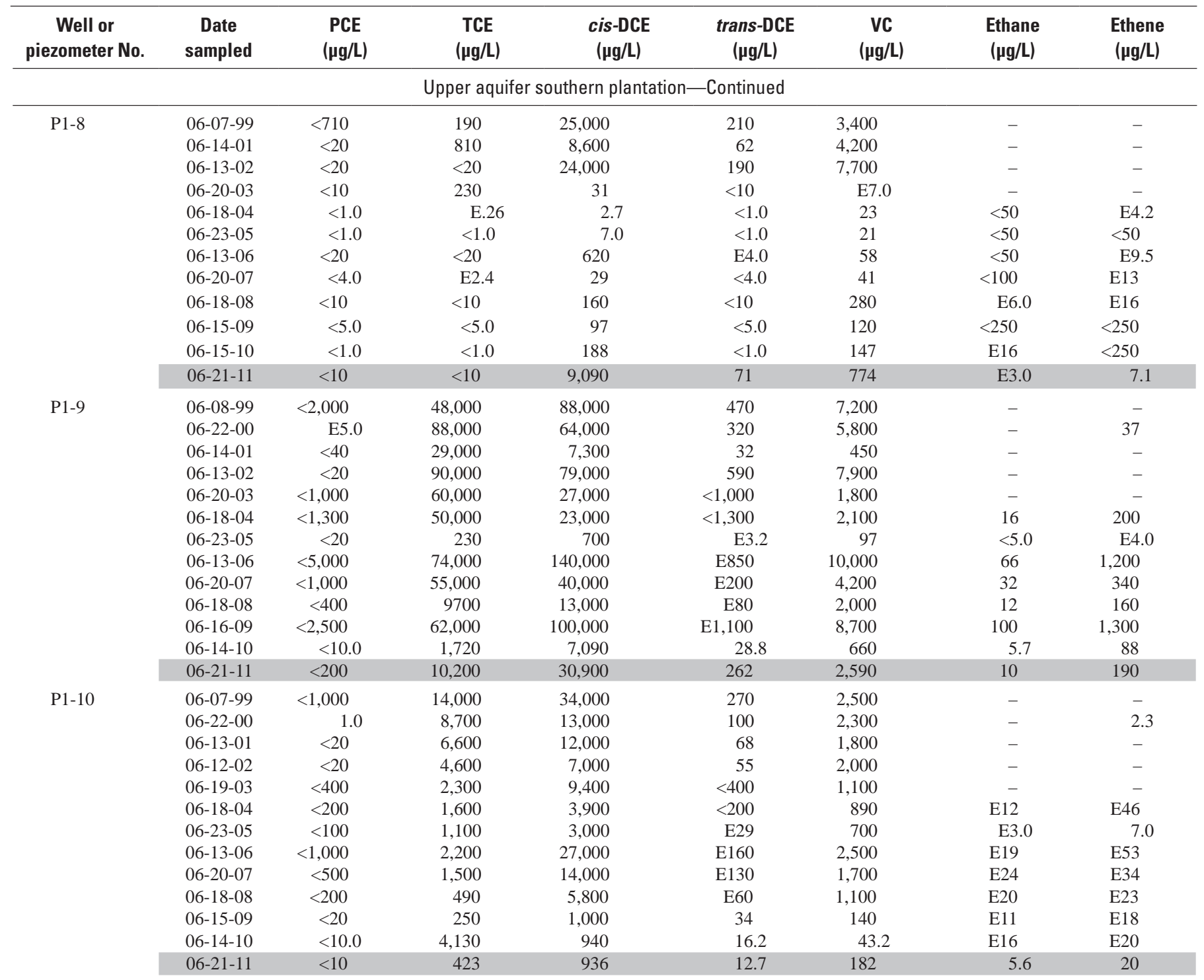


Table 3. Concentrations of selected volatile organic compounds in groundwater samples from monitoring wells and piezometers collected by the U.S. Geological Survey at Operable Unit 1, Naval Undersea Warfare Center, Division Keyport, Washington, $1999-2011$. -Continued

[All data except those shaded were published previously in Dinicola and others (2002), Dinicola (2003, 2004, 2006), Dinicola and Huffman (2004, 2006, 2007, 2009), and Dinicola and Huffman (2011). Laboratory data qualifier codes, such as "D" for dilution, are not shown. Volatile organic compounds (VOCs): PCE, tetrachloroethene; TCE, trichloroethene; cis-DCE, cis-1,2-dichloroethene; trans-DCE, trans-1,2-dichloroethene; VC, vinyl chloride; 1,1,1-TCA, 1,1,1-trichloroethane; 1,1-DCA, 1,1-dichloroethane; CA, chloroethane; 1,1-DCE, 1,1-dichloroethene; total BTEX, sum of benzene, toluene, ethylbenzene, and xylene; total CVOCs, sum of chlorinated volatile organic compounds. Abbreviations: E, estimated value; M, presence verified but not quantified; $\mu \mathrm{g} / \mathrm{L}$, microgram per liter; <, actual value is less than value shown; ND, not detected; -, not analyzed]

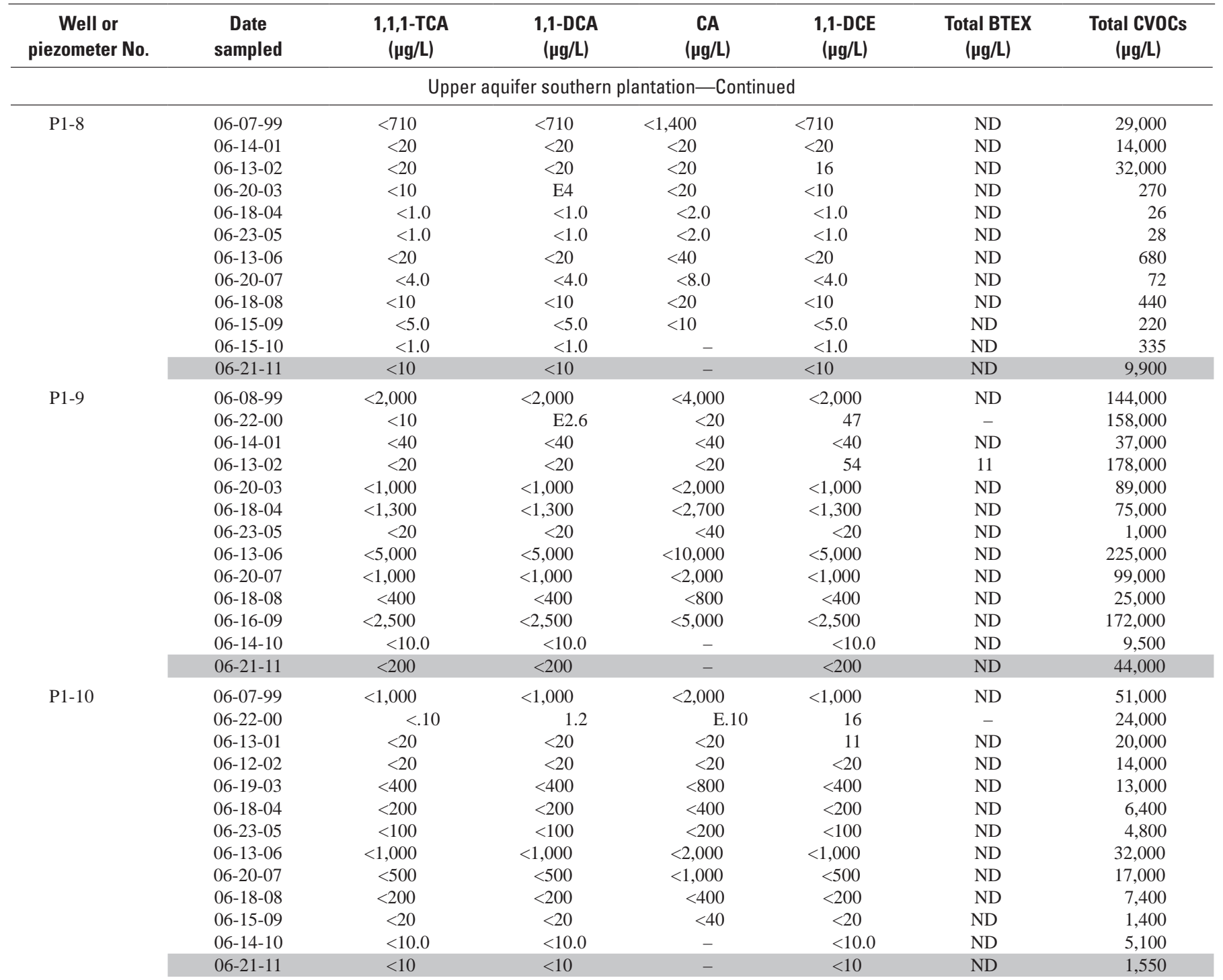


Table 3. Concentrations of selected volatile organic compounds in groundwater samples from monitoring wells and piezometers collected by the U.S. Geological Survey at Operable Unit 1, Naval Undersea Warfare Center, Division Keyport, Washington, 1999-2011.

-Continued

[All data except those shaded were published previously in Dinicola and others (2002), Dinicola (2003, 2004, 2006), Dinicola and Huffman (2004, 2006, 2007, 2009), and Dinicola and Huffman (2011). Laboratory data qualifier codes, such as "D" for dilution, are not shown. Volatile organic compounds (VOCs): PCE, tetrachloroethene; TCE, trichloroethene; cis-DCE, cis-1,2-dichloroethene; trans-DCE, trans-1,2-dichloroethene; VC, vinyl chloride; 1,1,1-TCA, 1,1,1-trichloroethane; 1,1-DCA, 1,1-dichloroethane; CA, chloroethane; 1,1-DCE, 1,1-dichloroethene; total BTEX, sum of benzene, toluene, ethylbenzene, and xylene; total CVOCs, sum of chlorinated volatile organic compounds. Abbreviations: E, estimated value; M, presence verified but not quantified; $\mu \mathrm{g} / \mathrm{L}$, microgram per liter; <, actual value is less than value shown; ND, not detected; -, not analyzed]

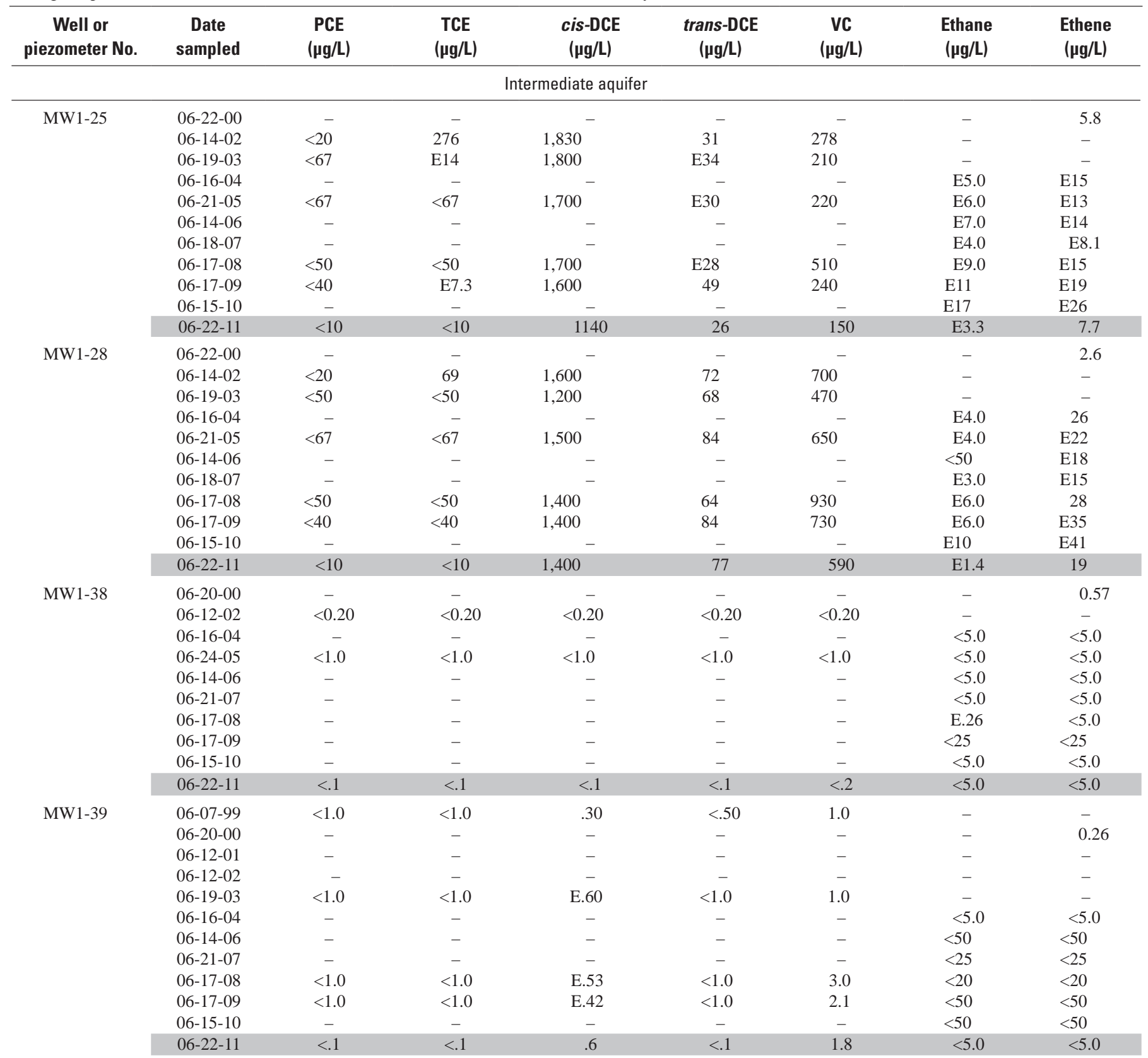


Table 3. Concentrations of selected volatile organic compounds in groundwater samples from monitoring wells and piezometers collected by the U.S. Geological Survey at Operable Unit 1, Naval Undersea Warfare Center, Division Keyport, Washington, $1999-2011$. -Continued

[All data except those shaded were published previously in Dinicola and others (2002), Dinicola (2003, 2004, 2006), Dinicola and Huffman (2004, 2006, 2007, 2009), and Dinicola and Huffman (2011). Laboratory data qualifier codes, such as "D" for dilution, are not shown. Volatile organic compounds (VOCs): PCE, tetrachloroethene; TCE, trichloroethene; cis-DCE, cis-1,2-dichloroethene; trans-DCE, trans-1,2-dichloroethene; VC, vinyl chloride; 1,1,1-TCA, 1,1,1-trichloroethane; 1,1-DCA, 1,1-dichloroethane; CA, chloroethane; 1,1-DCE, 1,1-dichloroethene; total BTEX, sum of benzene, toluene, ethylbenzene, and xylene; total CVOCs, sum of chlorinated volatile organic compounds. Abbreviations: E, estimated value; M, presence verified but not quantified; $\mu \mathrm{g} / \mathrm{L}$, microgram per liter; <, actual value is less than value shown; ND, not detected; -, not analyzed]

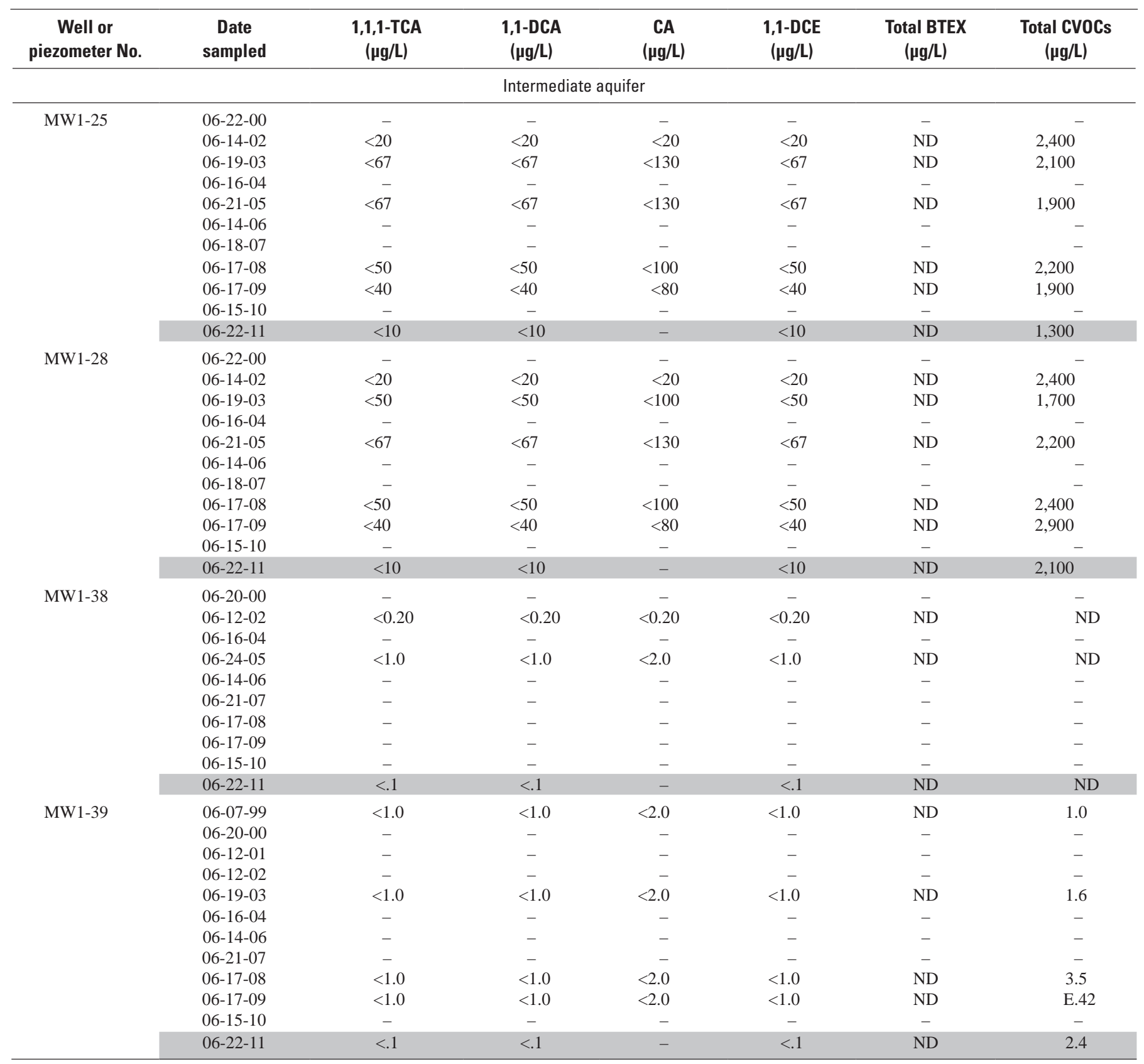


This page intentionally blank 
Publishing support provided by the U.S. Geological Survey

Publishing Network, Tacoma Publishing Service Center

For more information concerning the research in this report, contact the

Director, Washington Water Science Center

U.S. Geological Survey

934 Broadway, Suite 300

Tacoma, Washington 98402

http://wa.water.usgs.gov 


\section{总}

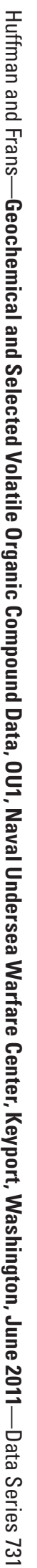

